\title{
Multiple Types of Calcium Channels in Acutely Isolated Rat Neostriatal Neurons
}

\author{
Katja Hoehn, Tim W. J. Watson, and Brian A. MacVicar \\ Neuroscience Research Group, University of Calgary, Calgary, Alberta, Canada T2N 4N1
}

\begin{abstract}
Voltage-activated high- and low-threshold $\mathrm{Ca}^{2+}$ currents were studied using whole-cell voltage-clamp techniques and fura-2 fluorescence measurements of intracellular $\mathrm{Ca}^{2+}$ in neurons acutely isolated from rat neostriatum. High-threshold $\mathrm{Ca}^{2+}$ currents activated around $-\mathbf{4 0} \mathrm{mV}$ and were present in at least $95 \%$ of neostriatal neurons. The maximum current, 736 \pm 44 pA (mean \pm SEM, $n=141$ ), was observed around 0 $\mathrm{mV}$. In $70 \%$ of neurons, high-threshold $\mathrm{Ca}^{2+}$ currents exhibited both inactivating and noninactivating components. The majority of the high-threshold $\mathrm{Ca}^{2+}$ currents appeared to belong neither to the "L-type" nor the "N-type" classification, since $\omega$-conotoxin (5 $\mu \mathrm{M}$ ) decreased this current by only $29 \%$ and nimodipine $(10 \mu \mathrm{M})$ decreased the noninactivating component of this current by only $17 \%$.
\end{abstract}

A low-threshold transient (T-type) $\mathrm{Ca}^{2+}$ current was observed in $40 \%$ of neurons. When both T-type and highthreshold $\mathrm{Ca}^{2+}$ currents were present, their maximum amplitudes were $78 \pm 7 \mathrm{pA}$ and $800 \pm 57 \mathrm{pA}$, respectively (mean \pm SEM, $n=58$ ). At a holding potential of $-100 \mathrm{mV}$, the T-type $\mathrm{Ca}^{2+}$ current activated around $-60 \mathrm{mV}$, with maximum current near $-40 \mathrm{mV}$. Steady-state inactivation of the T-type $\mathrm{Ca}^{2+}$ current was observed at holding potentials positive to $-125 \mathrm{mV}$, and the current was half-inactivated at $-88 \mathrm{mV}$. Recovery from inactivation to $90 \%$ of maximum occurred within 800 msec. $\mathrm{Mn}^{2+}$ or $\mathrm{Co}^{2+}(3 \mathrm{~mm}$ ) blocked both highthreshold and $\mathrm{T}$-type $\mathrm{Ca}^{2+}$ currents, whereas $\mathrm{Cd}^{2+}(25 \mu \mathrm{M})$ or verapamil (50 $\mu \mathrm{M}$ and $150 \mu \mathrm{M}$ ) preferentially blocked highthreshold over T-type $\mathrm{Ca}^{2+}$ currents.

In response to depolarization by $50 \mathrm{~mm} \mathrm{K+}$, fura-2 fluorescence measurements showed increased intracellular $\mathrm{Ca}^{2+}$ in both the soma and the proximal dendrites of neostriatal neurons that was markedly reduced by $25 \mu \mathrm{M} \mathrm{Cd}^{2+}$. These findings suggest that high-threshold $\mathrm{Ca}$ channels are present in both the soma and proximal dendrites of neostriatal neurons.

[Key words: striatum, calcium, fura-2, ion channels, nimodipine, verapamil, conotoxin, acute isolation, voltageclamp, imaging, basal ganglia]

\footnotetext{
Received July 15, 1992; revised Sept. 8, 1992; accepted Sept. 29, 1992.

We thank Mr. Spencer Borg for software development and Drs. Steven Barnes, Lori Mudrick-Donnon, and Larry Haynes and Mr. D. Fraser for comments on the manuscript. This work was supported by the Medical Research Council (MRC) Canada and The Parkinson Foundation of Canada. K.H. is an MRC and Alberta Heritage Foundation for Medical Research (AHFMR) Postdoctoral Fellow. T.W.J.W. is an AHFMR Clinical Investigator. B.A.M. is an AHFMR Scholar and an MRC Scientist.

Correspondence should be addressed to Dr. Katja Hoehn at the above address. Copyright (C) 1993 Society for Neuroscience 0270-6474/93/131244-14\$05.00/0
}

Neuronal voltage-dependent $\mathrm{Ca}$ channels are involved in the mediation of intracellular processes such as neurotransmitter release, enzyme activation, gene expression, and excitotoxicity. In addition, the kinetic properties and spatial distribution of $\mathrm{Ca}$ channels on the cell surface are major determinants of the firing patterns and input-output characteristics of various neuronal cell types (Llinás, 1988). There is substantial electrophysiological and pharmacological evidence for multiple types of voltagedependent Ca channels (Carbone and Lux, 1984; Nowycky et al., 1985; Fox et al., 1987; Bean, 1989). Low-voltage-activated Ca channels have been referred to as LVA or "T-type" (transient), depending on the classification scheme (Carbone and Lux, 1984; Fox et al., 1987; Tsien et al., 1988; Swandulla et al., 1991). High-voltage-activated Ca channels (HVA; Carbone and Lux, 1984) have been subdivided by various authors into "L" (longlasting), "N" (neither T nor L), and "P" (Purkinje) subtypes according to kinetic and pharmacological criteria (Fox et al., 1987; Tsien et al., 1988, Llinás et al., 1989). However, recent studies indicate that the biophysical and pharmacological classification of different types of HVA Ca channels is not as straightforward as was initially thought (Aosaki and Kasai, 1989; Plummer et al., 1989; reviewed by Hess, 1990; Sher and Clementi, 1991; Bertolino and Llinás, 1992). Indeed, molecular biological approaches suggest that at least eight different $\mathrm{Ca}$ channels are expressed in the brain (Snutch et al., 1990), and there is evidence that these Ca channels are differentially distributed among various CNS regions (Regan et al., 1991).

The neostriatum is the primary site of afferent input to the basal ganglia. The firing patterns of neostriatal output neurons have an important influence on the functioning of the extrapyramidal motor system (Gerfen, 1992). The presence of voltage-dependent $\mathrm{Ca}$ channels in rat neostriatal neurons has been inferred from current-clamp studies (Kita et al., 1985b; Misgeld et al., 1986; Calabresi et al., 1987, 1990) and single-electrode voltage-clamp studies (Cherubini and Lanfumey, 1987). There is general agreement that neostriatal neurons possess highthreshold $\mathrm{Ca}$ channels capable of generating $\mathrm{Ca}^{2+}$ spikes. It has been shown that these $\mathrm{Ca}^{2+}$ spikes are prolonged by the " $\mathrm{L}$ type" Ca channel agonist Bay K 8644 (Cherubini and Lanfumey, 1987). Physiological evidence for the existence of low-threshold Ca channels (Calabresi et al., 1987; Cherubini and Lanfumey, 1987) is less compelling. Neostriatal neurons do not exhibit rhythmic burst discharge patterns (Calabresi et al., 1987; Galarraga et al., 1989) characteristic of neurons with prominent low-threshold $\mathrm{Ca}^{2+}$ spikes (Llinás and Yarom, 1981a; Jahnsen and Llinás, 1984; Llinás, 1988). Although both low- and highthreshold Ca channels have recently been demonstrated in cultured fetal neostriatal neurons (Bargas et al., 1991), the size and types of $\mathrm{Ca}^{2+}$ currents exhibited by neurons in culture can be 
influenced profoundly by cell culture conditions (Yaari et al., 1987; Doerner et al., 1988; Plummer et al., 1989; Boland and Dingledine, 1990).

In the present study, $\mathrm{Ca}^{2+}$ currents recorded from acutely isolated adult rat neostriatal neurons were analyzed using wholecell voltage clamp. The use of cells acutely isolated from the intact environment of the nervous system avoids the above problems associated with cultured neurons. Moreover, the limited dendritic arborization of acutely isolated neurons significantly improves uniformity of voltage control throughout the neuron. Three main questions are addressed in this article. (1) What types of $\mathrm{Ca}^{2+}$ currents are present in ncostriatal neurons, and what are their distribution and relative amplitude? (2) What are the pharmacological characteristics of $\mathrm{Ca}^{2+}$ currents in the neostriatum? (3) Is there a preferential localization of highthreshold $\mathrm{Ca}^{2+}$ currents in the soma or proximal dendrites of neostriatal neurons? Our results indicate that the majority of high-threshold $\mathrm{Ca}^{2+}$ currents in neostriatal neurons appear to be neither "N-" nor "L-type." We also present evidence that high-threshold Ca channels are present in both the soma and proximal dendrites of neostriatal neurons.

Some of these results have been presented in preliminary form (Hoehn et al., 1991).

\section{Materials and Methods}

Cell preparation. Neostriatal neurons were isolated using a technique adapted from Kay and Wong (1986). Male Sprague-Dawley rats (21$28 \mathrm{~d}$ postnatal) were decapitated and their brains removed rapidly and immersed in ice-cold artificial cerebrospinal fluid (aCSF) containing (in mM) $124 \mathrm{NaCl}, 5 \mathrm{KCl}, 26 \mathrm{NaHCO}_{3}, 2 \mathrm{CaCl}_{2}, 1.3 \mathrm{MgCl}_{2}$, and 10 D-glucose (pH 7.4, 280 mOsm) equilibrated with $95 \% \mathrm{O}_{2}, 5 \% \mathrm{CO}_{2}$. The cerebrum was bisected in the coronal plane with a razor blade and the anterior half glued and secured with blocks of $4 \%$ low-melt agarose to a wedge of Plexiglas inclined at $30^{\circ}$. Transverse slices $(400 \mu \mathrm{m}$ thick, $30^{\circ}$ rostral-up from the horizontal) containing neostriatum as well as overlying frontal cortex were cut with a vibratome. Slices were transferred to a spinner flask containing $30 \mathrm{ml}$ of low-Ca ${ }^{2+}(0.1 \mathrm{mM})$, high$\mathrm{Mg}^{2+}(3.2 \mathrm{~mm}) \mathrm{aCSF}$ at $33^{\circ} \mathrm{C}$ to which $1 \mathrm{~mm}$ kynurenic acid, $40 \mathrm{mg}$ of trypsin $(9000 \mathrm{U} / \mathrm{mg})$, and $20 \mathrm{mg}$ of hyaluronidase $(1500 \mathrm{U} / \mathrm{mg})$ were added. The slices were stirred gently with a magnetic stirrer at a rate sufficient to prevent them from settling and the solution was bubbled continuously with $95 \% \mathrm{O}_{2}, 5 \% \mathrm{CO}_{2} . \Lambda$ fter $90 \mathrm{~min}$, slices were rinsed with $60 \mathrm{ml}$ of aCSF and transferred for storage to a holding chamber filled with continuously bubbled aCSF at $21^{\circ} \mathrm{C}$. Slices were used within 2-8 hr of preparation. When needed, a slice was transferred to HEPESbuffered Dulbecco's Modified Eagle's Medium (DMEM) containing 1 $\mathrm{mm}$ kynurenic acid and $0.65 \mathrm{mg} / \mathrm{ml}$ of trypsin inhibitor $(50 \mathrm{U} / \mathrm{mg})$. Under a dissecting microscope, the neostriatum was isolated with a scalpel blade and cut into $1-2 \mathrm{~mm}^{2}$ blocks, and the cells were dissociated by trituration in $0.5 \mathrm{ml}$ DMEM solution using a fire-polished Pasteur pipette with an approximate tip diameter of $1 \mathrm{~mm}$. For fura- 2 imaging experiments, the DMEM also contained the acetoxymethyl form of fura-2 (fura-2/AM; Molecular Probes) to load the cells with the $\mathrm{Ca}^{2+}$ indicator dye. The suspension of dissociated cells was then transferred to a $0.5 \mathrm{ml}$ perfusion chamber mounted on a Zeiss IM-35 inverted microscope. Neurons were allowed to settle on poly-L-lysine-coated coverslips.

Electrophysiological recording. Ten minutes after cells were placed on the coverslips, the DMEM was replaced via superfusion at $1-1.5 \mathrm{ml} /$ min with the extracellular recording solution containing (in $\mathrm{Mm}$ ) 90 $\mathrm{NaCl}, 40$ tetraethylammonium chloride (TEA-Cl), $10 \mathrm{HEPES}, 5 \mathrm{CaCl}_{2}$, 4 4-aminopyridine, and 0.0009 tetrodotoxin (TTX). The solution was continuously bubbled with $100 \% \mathrm{O}_{2}$ and maintained at room temperature (pH 7.4, $\sim 275 \mathrm{mOsm}$ ). Some studies were conducted in $0 \mathrm{~mm}$ $\mathrm{NaCl}, 130 \mathrm{~mm}$ TEA-Cl-containing extracellular solution that was otherwise identical to the one described above. All data illustrated in the figures were obtained in $\mathrm{Na}^{+}$-free extracellular medium except those in Figure 6.

The whole-cell variation of the patch-clamp technique was used (Hamill et al., 1981). Patch electrodes were pulled from thin-walled glass (1.5 mm o.d.; TW 150 F-4, World Precision Instruments) in four stages on a Flaming-Brown micropipette puller (model P-87). The intracellular solution contained (in $\mathrm{mM}$ ) 70 trizma phosphate, 25 trizma base, 40 TEA-Cl, 11 EGTA, $2.0 \mathrm{Mg}-\mathrm{ATP}$, and $0.3 \mathrm{Na}-\mathrm{GTP}(\mathrm{pH} 7.30, \sim 270$ mOsm). To decrease the rundown of $\mathrm{Ca}^{2+}$ currents (Forscher and $\mathrm{Ox}$ ford, 1985), $20 \mathrm{~mm}$ phosphocreatine and $50 \mathrm{U} / \mathrm{ml}$ of creatine phosphokinase were added to the intracellular solution in some experiments and the concentration of trizma phosphate was decreased to $52 \mathrm{~mm}$ to maintain osmolality. Creatine phosphokinase, Mg-ATP, Na-GTP, and phosphocreatine were added to the intracellular solution just prior to use. No difference in $\mathrm{Ca}^{2+}$ current characteristics was noted with the two solutions except for a small decrease in the rate of high-threshold $\mathrm{Ca}^{2+}$ current rundown. Electrodes filled with this solution had a resistance of 3-7 M $\Omega$ when tested in recording solution. A $7 \mathrm{mV}$ junction potential was measured between the electrode and bath solution. Voltage command levels were not compensated and are thus shifted $7 \mathrm{mV}$ in the positive direction.

Current recordings were obtained using a single-electrode voltageclamp amplifier (Axopatch-1D) and were filtered at $5 \mathrm{kHz}(-3 \mathrm{~dB}$ point). Step depolarizations from the holding potential were applied at intervals of 3-10 sec to allow $\mathrm{Ca}$ channels to recover from inactivation. Compensation circuitry was used to minimize series resistance errors $\left(R_{s}\right)$ and $50-80 \%$ of the series resistance could be compensated. Data were digitized and analyzed using pCLAMP software (Axon Instruments). All currents were leak subtracted by one of two methods. In most cases, a linear leak component was digitally subtracted from current records in order to isolate the $\mathrm{Ca}^{2+}$ current. In some cases (as indicated in the figures), an inactivating component of the $\mathrm{Ca}^{2+}$ current was isolated and leak and capacitative currents were eliminated by subtracting currents obtained from a holding potential of $-60 \mathrm{mV}$ (where inactivation of $\mathrm{T}$-type $\mathrm{Ca}^{2+}$ currents was largely complete) from currents obtained from a holding potential of $-100 \mathrm{mV}$ (where inactivation was minimal). In some neurons, $\mathrm{Ca}^{2+}$ currents could not be clamped, as judged by the lack of smoothly voltage-dependent current activation and a delay in onset of the currents. These neurons generally had longer processes and somewhat higher whole-cell capacitances than the cells in which $\mathrm{Ca}^{2}$ ! currents could be clamped and were not included in the analysis.

Intracellular $\mathrm{Ca}^{2+}$ imaging. The acetoxymethyl form of fura-2 (50 $\mu \mathrm{g}$ ) was dissolved in dimethyl sulfoxide with pluronic acid, added to 3 $\mathrm{ml}$ of DMEM containing $1 \mathrm{~mm}$ kynurenic acid and $0.6 \mathrm{mg} / \mathrm{ml}$ trypsin inhibitor, and then sonicated to ensure that the dye was dispersed. Cells isolated in fura-containing DMEM were allowed to settle on coverslips for $20 \mathrm{~min}$ while in fura-containing DMEM. The DMEM was then replaced by superfusing the bath volume $(500 \mu \mathrm{l})$ with continuously bubbled aCSF at $1.0-1.5 \mathrm{ml} / \mathrm{min}$. Experiments were performed at room temperature. When extracellular $\mathrm{K}^{+}$was increased, $\mathrm{NaCl}$ was replaced with an equal amount of $\mathrm{KCl}$.

Cells were observed with a $63 \times$ plan-neofluar water immersion objective (Zeiss; $1.25 \mathrm{NA}$ ) and were illuminated using a $75 \mathrm{~W}$ xenon lamp powered by a stabilized power supply. For fura- 2 imaging, cells were illuminated at $340 \mathrm{~nm}$ or $380 \mathrm{~nm}$ and video images were obtained by a CCD camera (MTI CCD-72) coupled to an image intensifier (KS1381, Video Scope). Video images (averages of eight frames obtained at $30 \mathrm{~Hz}$ ) were digitized to $512 \times 480$ pixel arrays and were analyzed with an Imaging Technology 151 image processor (Cambridge, MA) controlled by a computer (Packard-Bell 386). Pixel ratios of 340:380 $\mathrm{nm}$ fluorescence intensities were calculated.

Materials. All inorganic salts were purchased from Fisher Scientific (Fair Lawn, NJ). Trypsin (type XI), hyaluronidase (type V), Mg-ATP, Na-GTP (type IIS), di(Tris)-phosphocreatine, creatine phosphokinase (from bovine heart, type III), \pm -verapamil hydrochloride, kynurenic acid, TTX, TEA-Cl, 4-aminopyridine, $\omega$-conotoxin GVIA ( $70 \%$ peptide content), and dimethyl sulfoxide were purchased from Sigma Chemical Co. (St. Louis, MO); trypsin inhibitor (from chicken egg white) was purchased from Boehringer Mannheim (Laval, Quebec, Canada); and fura-2/AM and pluronic-F-127 were purchased from Molecular Probes (Eugene, OR). DMEM was purchased from GIBCO Laboratories (Grand Island, NY). Ethosuximide was a gift from Parke-Davis (Brockville, Ontario, Canada), and nimodipine was a gift from Dr. Alexander Scriabine, Miles Institute for Preclinical Research (West Haven, CT).

Drugs were added hyperosmotically to the extracellular medium from 1000-fold concentrated stock solutions in distilled $\mathrm{H}_{2} \mathrm{O}$. Exceptions to this were nimodipine, which was dissolved in absolute ethanol, and $\omega$-conotoxin, which was dissolved in distilled $\mathrm{H}_{2} \mathrm{O}$ containing $1 \mathrm{mg} / \mathrm{ml}$ 

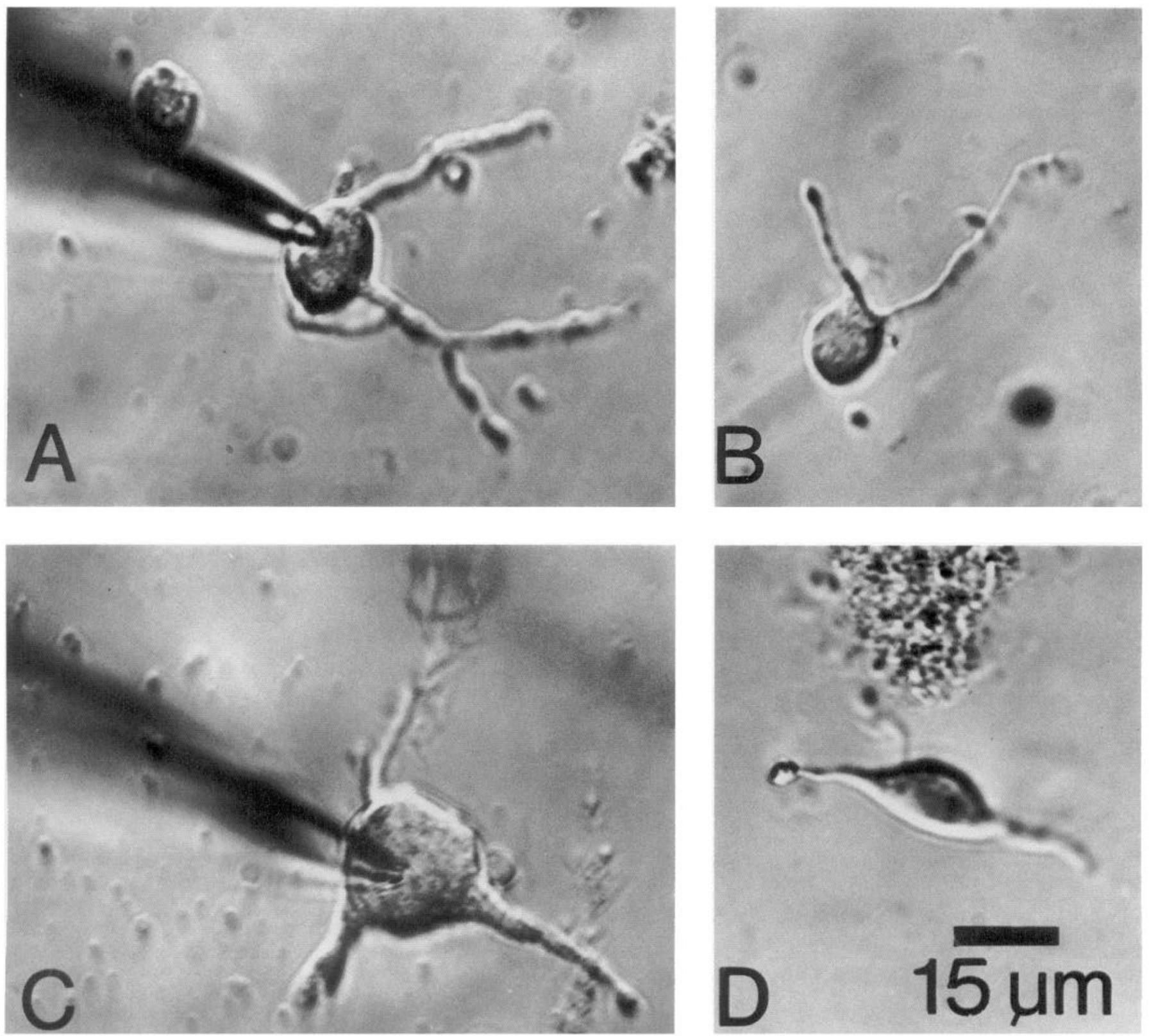

Figure 1. Photomicrographs of acutely isolated striatal neurons. In $A$ and $C$, the recording electrode can be seen following formation of a tight seal on the cell membrane. Scale bar applies to all panels.

bovine serum albumin. Equivalent concentrations of ethanol or bovine serum albumin alone did not affect $\mathrm{Ca}^{2+}$ currents. Aliquots of stock solutions of verapamil, nimodipine, and $\omega$-conotoxin were kept frozen, and nimodipine was kept in the dark until immediately prior to use.

\section{Results}

\section{Acute isolation of neostriatal neurons}

Examples of the morphology of neostriatal neurons following the dissociation procedure are shown in Figure 1. As reported in histological studies (Chang et al., 1982), neostriatal neurons exhibited a continuous range of cell soma size. The majority (greater than $95 \%$ ) of the cell somata of dissociated neostriatal neurons measured 10-20 $\mu \mathrm{m}$ across their widest diameter, thus corresponding in size and abundance to medium spiny striatal neurons (Mensah and Deadwyler, 1974; Chang et al., 1982). In addition, dissociation yielded some larger neurons with soma diameters up to $40 \mu \mathrm{m}$. Obvious differences in current properties between neurons of different sizes were not observed. For consistency, the majority of neurons included in the present study corresponded in size to medium spiny neurons and had only one or two thin primary dendrites.

\section{$\mathrm{Ca}^{2+}$ current characteristics and distribution among neostriatal neurons}

The characteristics and distribution of $\mathrm{Ca}^{2+}$ currents were studied in 210 acutely isolated neostriatal neurons using intra- and extracellular solutions designed to block $\mathrm{Na}^{+}$and $\mathrm{K}^{+}$currents and reveal $\mathrm{Ca}^{2+}$ currents (see Materials and Methods). Three additional lines of evidence show that the currents studied were indeed $\mathrm{Ca}^{2+}$ currents: (1) in 4 of 4 neurons the $\mathrm{Ca}^{2+}$ current was decreased substantially when $5 \mathrm{~mm} \mathrm{CaCl}$ was substituted by 1 

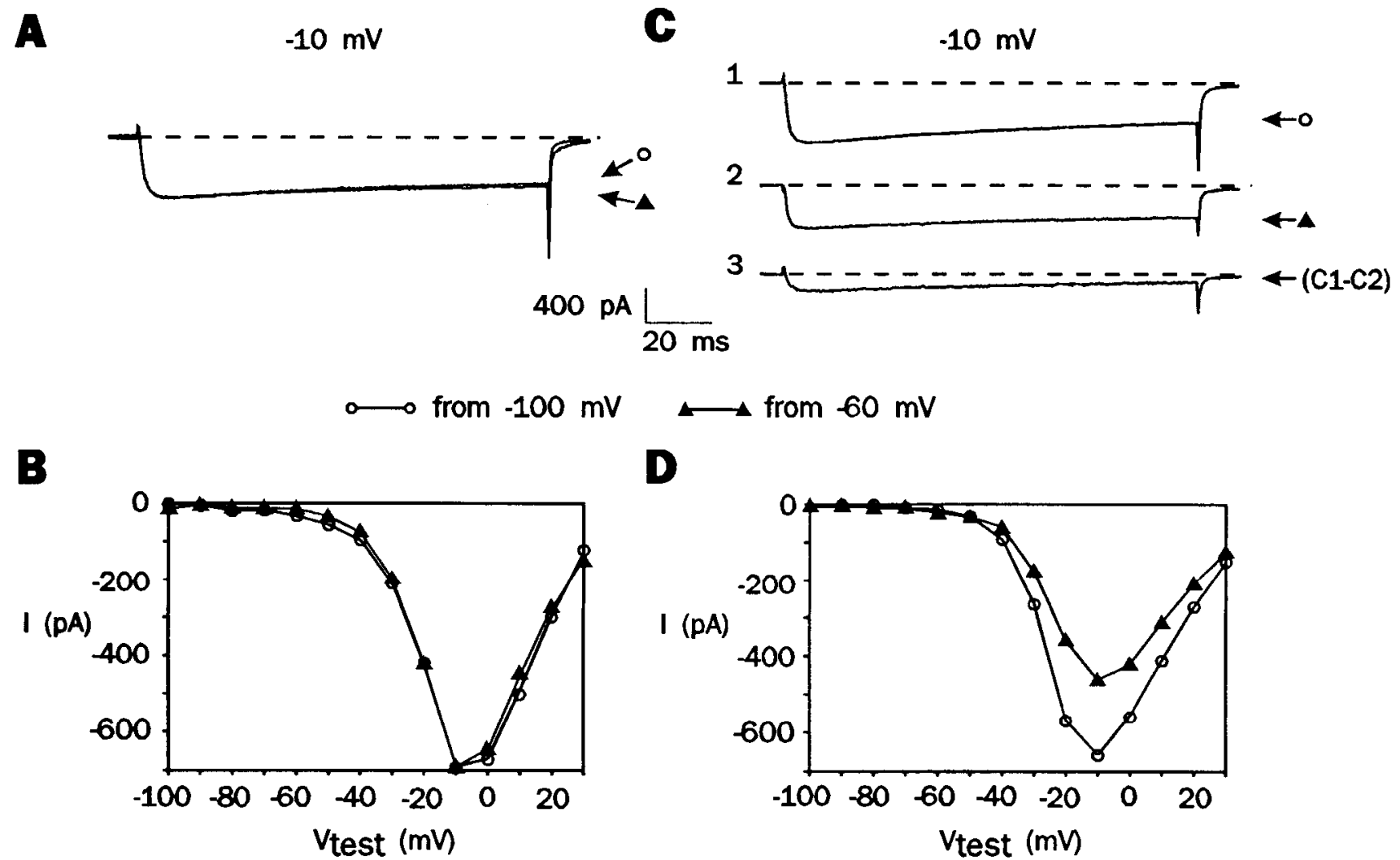

D

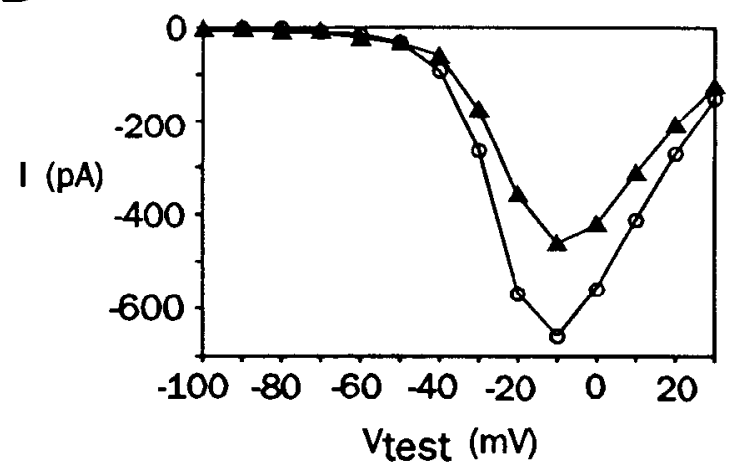

Figure 2. Diversity of high-threshold $\mathrm{Ca}^{2+}$ currents in striatal neurons. $A$ and $B$ illustrate data from a cell representative of $30 \%$ of striatal neurons in that it exhibited only the $\mathrm{HVA}_{s}$ type of high-threshold $\mathrm{Ca}^{2+}$ current. $\mathrm{Ca}^{2+}$ current recordings in $A$ illustrate the absence of steady-state inactivation. Currents elicited by $150 \mathrm{msec}$ steps to the test potential $(-10 \mathrm{mV})$ were not affected by a change in holding potential from $-100 \mathrm{mV}(0)$ to -60 $\mathrm{mV}(\Delta)$. Similarly, the peak $\mathrm{Ca}^{2+}$ current-voltage relationship illustrated in $B$ was not affected by the change in holding potential. $C$ and $D$ illustrate data from a cell representative of $70 \%$ of striatal neurons in that it had both high-threshold sustained $\left(\mathrm{HVA}_{s}\right) \mathrm{Ca}^{2+}$ currents and high-threshold inactivating (HVA $)_{l} \mathrm{Ca}^{2+}$ currents. Current recordings in $C$ show the different amplitude and shape of $\mathrm{Ca}^{2+}$ currents elicited from holding potentials of $-100 \mathrm{mV}$ and $-60 \mathrm{mV}$. All currents in this and subsequent figures (except Fig. 6) were leak subtracted. The inactivating current component of the high-threshold $\mathrm{Ca}^{2+}$ current $\left(\mathrm{HVA}_{I}, \mathrm{Cl}-\mathrm{C2}\right.$ ) was isolated by subtracting the current obtained from a holding potential of $-60 \mathrm{mV}$ from the current obtained from a holding potential of $-100 \mathrm{mV}$. The peak $\mathrm{Ca}^{2+}$ current-voltage relationship is illustrated in $D$. Note that the test potential at which the maximum $\mathrm{Ca}^{2+}$ current was observed $(-10 \mathrm{mV})$ did not change. The broken lines indicate 0 current.

$\mathrm{mm} \mathrm{CaCl}, 10 \mathrm{~mm} \mathrm{MgCl}_{2}$-containing solution; (2) in 34 of 34 additional neurons studied, $\mathrm{Ba}^{2+}(2.5$ or $5 \mathrm{~mm})$ supported current through these channels; and (3) the currents were blocked by inorganic and organic $\mathrm{Ca}$ channel blockers as reported below.

Different $\mathrm{Ca}^{2+}$ currents were distinguished primarily on the basis of differences in activation range [high threshold (HVA) beginning around $-40 \mathrm{mV}$ and low threshold around $-60 \mathrm{mV}$ ] and the presence or absence of steady-state inactivation as determined by a change in amplitude of the $\mathrm{Ca}^{2+}$ current following a change in holding potential from $-100 \mathrm{mV}$ to $-60 \mathrm{mV}$. As in other types of ncurons (Nowycky ct al., 1985; Tsien et al., 1988), three types of $\mathrm{Ca}^{2+}$ currents were observed in acutely isolated neostriatal neurons. A sustained $\mathrm{HVA} \mathrm{Ca}^{2+}$ current $\left(\mathrm{HVA}_{s}\right)$ was defined as the current that activated around -40 $\mathrm{mV}$ and persisted when elicited from a holding potential of -60 $\mathrm{mV}$. An inactivating $\mathrm{HVA} \mathrm{Ca}^{2+}$ current $\left(\mathrm{HVA}_{t}\right)$ was defined as the current that activated around $-40 \mathrm{mV}$ but was inactivated by a change in holding polential from $-100 \mathrm{mV}$ to $-60 \mathrm{mV}$. The third type of $\mathrm{Ca}^{2+}$ current, the low-threshold transient (Ttype) current, activated around $-60 \mathrm{mV}$ and was also inactivated by a change in holding potential from $-100 \mathrm{mV}$ to -60 mV. As defined above, the kinetics of the HVA, $\mathrm{HVA}_{l}$, and T-type currents correspond roughly to the "L," "N," and " $T$ " $\mathrm{Ca}^{2+}$ currents defined by Tsien and colleagues (Nowycky et al.,
1985; Tsien et al., 1988). However, the results of pharmacological experiments in neostriatal neurons argue against a direct correspondence between the $\mathrm{HVA}_{s}$ and $\mathrm{HVA}_{i}$ currents and "L" and " $N$ " currents (see below).

High-threshold $\mathrm{Ca}^{2+}$ currents were present in over $95 \%$ of neurons (Fig. 2). These currents typically activated around -40 $\mathrm{mV}$ and reached a maximum amplitude of $736 \pm 41 \mathrm{pA}$ (mean \pm SEM, 141 neurons) between $-10 \mathrm{mV}$ and $0 \mathrm{mV}$. Figure 2, $A$ and $B$, illustrates $\mathrm{Ca}^{2+}$ currents recorded from a neuron typical of $30 \%$ of neostriatal neurons in that it exhibited only the $\mathrm{HVA}_{\mathrm{s}}$ type of high-threshold $\mathrm{Ca}^{2+}$ current. The remaining $70 \%$ of neurons ( 35 of 51) exhibited both the $\mathrm{HVA}_{s}$ and $\mathrm{HVA}_{I}$ components of high-threshold $\mathrm{Ca}^{2+}$ currents as indicated by a decrease in amplitude of the high-threshold $\mathrm{Ca}^{2+}$ current when it was elicited from less negative holding potentials (Fig. $2 C, D$ ). The voltages at which the maximum current amplitude and the activation of the high-threshold currents occurred did not change with a change in holding potential from $-100 \mathrm{mV}$ to $-60 \mathrm{mV}$ (Fig. $2 B, D$ ). In the $70 \%$ of neurons exhibiting an $\mathrm{HVA}_{I}$ component, the amplitude of the maximum current (measured at either $-10 \mathrm{mV}$ or $0 \mathrm{mV}$ ) decreased from $881 \pm 101 \mathrm{pA}$ to 683 $\pm 95 \mathrm{pA}$ (mean $\pm \mathrm{SEM}, n=35$ ) with a change in holding potential from $-100 \mathrm{mV}$ to $-60 \mathrm{mV}$. Therefore, when present, the $\mathrm{HVA}_{I} \mathrm{Ca}^{2+}$ current represented only about $23 \%$ of the total 
A

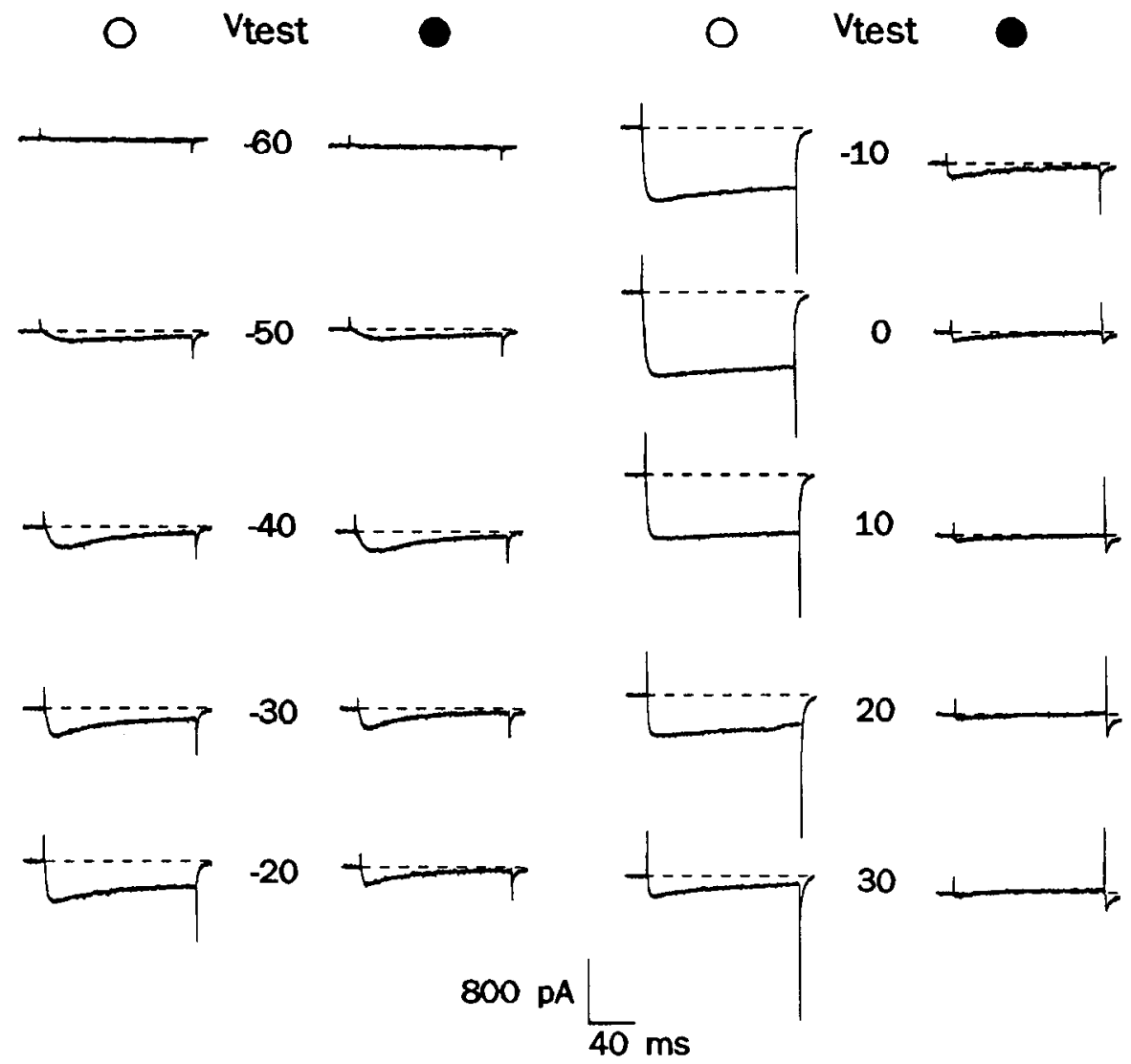

Figure 3. An example of the T-type $\mathrm{Ca}^{2+}$ currents that were present in $40 \%$ of striatal neurons. $A$, Current recordings of $150 \mathrm{msec}$ steps to test potentials $\left(V_{\text {tess }}\right)$ shown. The left column $(O)$ illustrates combined $\mathrm{HVA}_{s}$ and T-type $\mathrm{Ca}^{2+}$ currents obtained from a holding potential of $-100 \mathrm{mV}$. Note the presence of both an inactivating component of $\mathrm{Ca}^{2+}$ current and a sustained $\mathrm{Ca}^{2+}$ current that reaches maximum at $0 \mathrm{mV}$. The right column (๑) illustrates inactivating current that was isolated by subtracting currents obtained from a holding potential of $-60 \mathrm{mV}$ from currents obtained from a holding potential of $-100 \mathrm{mV}$. In this cell the inactivating current appears to consist only of the T-type $\mathrm{Ca}^{2+}$ current and there is no evidence for an $\mathrm{HVA}_{2} \mathrm{Ca}^{2+}$ current. $B$, The current-voltage relationship of the peak $\mathrm{Ca}^{2+}$ currents from $A$ illustrates the two separate maxima corresponding to the T-type and $\mathrm{HVA}_{S} \mathrm{Ca}^{2+}$ currents. The broken lines indicate 0 current.
B

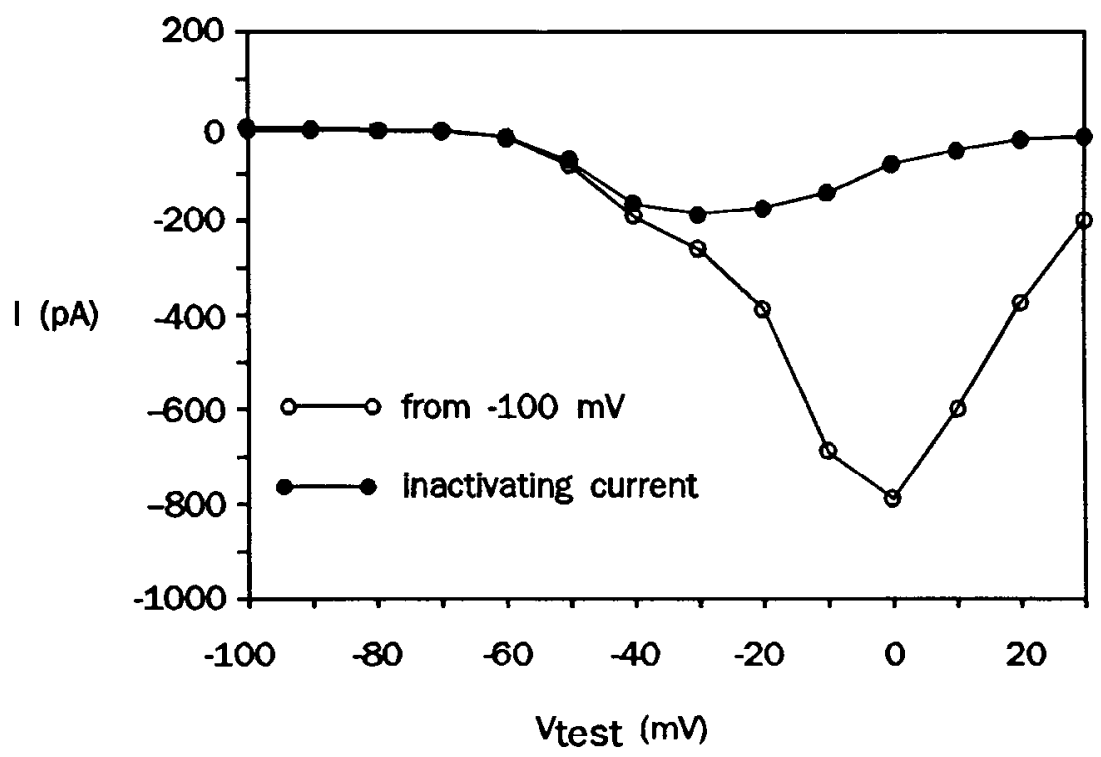

high-threshold $\mathrm{Ca}^{2+}$ current in neostriatal neurons. $\mathrm{HVA}_{S} \mathrm{Ca}^{2+}$ currents exhibited minimal inactivation during the $150 \mathrm{msec}$ depolarization. Inactivation of HVA, currents during the 150 msec depolarization was variable and ranged from minimal (e.g., Fig. 2C) to almost complete inactivation (see Fig. $4 A$ ).

In $40 \%$ (58 of 146) of neostriatal neurons a T-type $\mathrm{Ca}^{2+}$ current was observed from a holding potential of $-100 \mathrm{mV}$ (Fig. 3). This current began to activate around $-60 \mathrm{mV}$, and the peak current amplitude at $-40 \mathrm{mV}$ or $-30 \mathrm{mV}$ was $78 \pm 8 \mathrm{pA}$ (mean $\pm \mathrm{SEM}, n=58$ ). The $\mathrm{T}$-type $\mathrm{Ca}^{2+}$ current was totally inactivated at a holding potential of $-60 \mathrm{mV}$.

Some neurons possessed all three types of $\mathrm{Ca}^{2+}$ currents (Fig. 4). A possible correlation between the size of neostriatal neurons and the types of $\mathrm{Ca}^{2+}$ currents present was tested. Neurons were grouped according to capacitance, into small ( $\leq 6 \mathrm{pF}, 39$ of 146 neurons), medium (7-13 pF, 68 of 146 neurons), and large ( $\geq 14$ $\mathrm{pF}, 39$ of 146 neurons) neurons. The density of the combined high-threshold $\mathrm{Ca}^{2+}$ currents elicited from a holding potential 
of $-100 \mathrm{mV}$ was $89 \pm 11 \mathrm{pA} / \mathrm{pF}(n-39), 68 \pm 5 \mathrm{pA} / \mathrm{pF}(n$ $=68)$, and $65 \pm 5 \mathrm{pA} / \mathrm{pF}(n=39)$ in small, medium, and large neurons, respectively. Therefore, the distribution and magnitude of high-threshold $\mathrm{Ca}^{2+}$ currents among neurons of various sizes were not obviously different. There was, however, a difference in distribution of T-type $\mathrm{Ca}^{2+}$ currents in that a larger percentage of small neurons possessed these currents $(45 \%, 40 \%$, and $33 \%$ in small, medium, and large neurons, respectively), and when present they represented a greater fraction of the total cell $\mathrm{Ca}^{2+}$ current. The maximum magnitude of the T-type $\mathrm{Ca}^{2+}$ currents remained relatively constant at $89.7 \pm 14.6 \mathrm{pA}, 61.5$ $\pm 8.3 \mathrm{pA}$, and $94.2 \pm 11.7 \mathrm{pA}$ in small, medium, and large neurons, respectively. However, when compared in size to the maximum total high-threshold $\mathrm{Ca}^{2+}$ current elicited from a holding potential of $-100 \mathrm{mV}$, the $\mathrm{T}$-type $\mathrm{Ca}^{2+}$ current was $21 \%$ of the size of high-threshold $\mathrm{Ca}^{2+}$ currents in small neurons, $9 \%$ of the size of high-threshold $\mathrm{Ca}^{2+}$ currents in medium-sized neurons, and only $8 \%$ of the size of high-threshold $\mathrm{Ca}^{2+}$ currents in large neurons. Thus, the density of the $\mathrm{T}$-type $\mathrm{Ca}^{2+}$ was 17 $\pm 3 \mathrm{pA} / \mathrm{pF}(n=18), 7 \pm 1 \mathrm{pA} / \mathrm{pF}(n=27)$, and $6 \pm 1 \mathrm{pA} / \mathrm{pF}$ $(n=13)$ in small-, medium-, and large-sized neurons, respectively.

\section{Kinetics of activation and inactivation of $\mathrm{Ca}^{2+}$ currents}

Steady-state inactivation of the T-type $\mathrm{Ca}^{2+}$ current was measured by varying the holding potential from $-125 \mathrm{mV}$ to -50 $\mathrm{mV}$ for $3 \mathrm{sec}$ prior to activating the T-type $\mathrm{Ca}^{2+}$ current with a test potential of $-40 \mathrm{mV}$ (Fig. 5). At this potential the T-type $\mathrm{Ca}^{2+}$ current could be observed in virtual isolation from the high-threshold $\mathrm{Ca}^{2+}$ currents. Steady-state inactivation was observed when the holding potential was positive to $-125 \mathrm{mV}$. The current was half-inactivated at $-88 \mathrm{mV}$ and was totally inactivated at $-60 \mathrm{mV}$. The fractional current, normalized to the maximum current, was smoothly voltage dependent and was fit with the Boltzmann equation

$$
I / I_{\max }=\left\{1+\exp \left[-\left(V-V_{0.5}\right) / k\right]\right\}^{-1},
$$

where $I$ is peak current at $V, I_{\max }$ is the maximum current from a holding potential of $-125 \mathrm{mV}, V$ is the holding potential, $V_{0.5}$ is the half-inactivation value $(-87.6 \mathrm{mV})$, and $k$ is the slope constant, which in this case was found to be $-6.1 \mathrm{mV}$.

The voltage dependence of activation of the T-type $\mathrm{Ca}^{2+}$ current was examined by varying test potential pulses from a constant holding potential of $-100 \mathrm{mV}$. The T-type $\mathrm{Ca}^{2+}$ current was isolated by subtraction as described earlier, in neurons that did not exhibit an $\mathrm{HVA}_{1} \mathrm{Ca}^{2+}$ current. The curve was smoothly voltage dependent. The best fit of the curve with the Boltzmann equation was obtained when $V_{0.5}=-52.8 \mathrm{mV}$ and $k=5.8 \mathrm{mV}$. In a similar manner, the voltage dependence of activation of the $\mathrm{HVA}_{s} \mathrm{Ca}^{2+}$ current was obtained by varying test potentials from a holding potential of $-60 \mathrm{mV}$. The activation curve of the $\mathrm{HVA}_{S} \mathrm{Ca}^{2+}$ current was also smoothly voltage dependent and was best fit by the Boltzmann equation when $V_{0.5}=-21.6$ $\mathrm{mV}$ and $k=5.6 \mathrm{mV}$.

The recovery from inactivation of the $\mathrm{T}$-type $\mathrm{Ca}^{2+}$ current was also examincd and the results are shown in Figure 6. These studies were conducted by selecting neurons with a prominent T-type $\mathrm{Ca}^{2+}$ current and repolarizing them to $-100 \mathrm{mV}$ from a holding potential of $-60 \mathrm{mV}$ for various time periods before eliciting the low-threshold $\mathrm{Ca}^{2+}$ current in relative isolation with a test pulse to $-40 \mathrm{mV}$. Recovery to $90 \%$ was seen after 800 $\mathrm{msec}$ of repolarization.

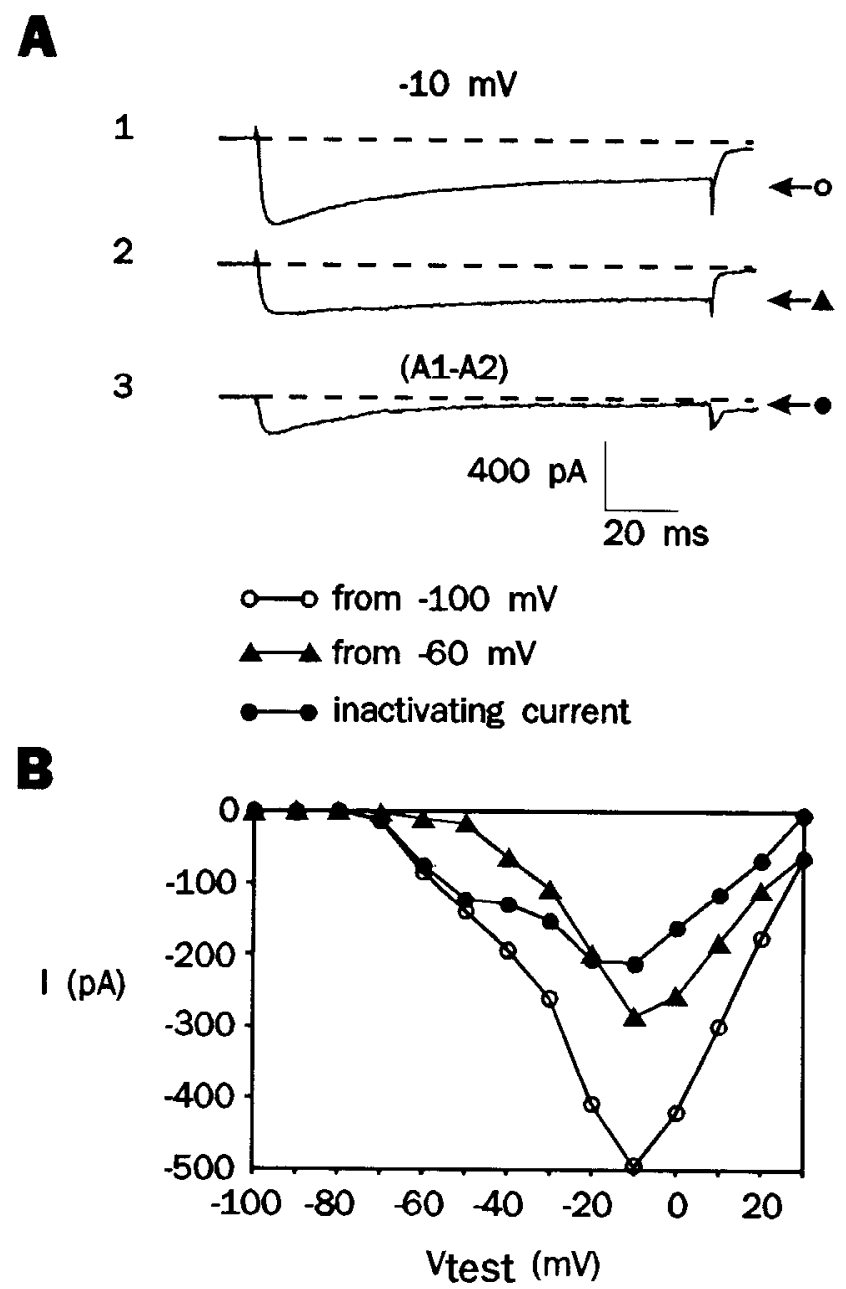

Figure 4. An example of a striatal neuron exhibiting all three types of $\mathrm{Ca}^{2+}$ currents. $A$, Current recordings of high-threshold $\mathrm{Ca}^{2+}$ currents obtained by a $150 \mathrm{msec}$ step to the test potential $(-10 \mathrm{mV})$ from holding potentials of $-100 \mathrm{mV}(0)$ and $60 \mathrm{mV}(\Delta)$. The inactivating current $(\boldsymbol{C}, A 1-A 2)$ was obtained by subtraction as described in the Figure 3 caption. The broken lines indicate 0 current. In this cell the HVA current exhibits inactivation during the $150 \mathrm{msec}$ step. $B$, Current-voltage relation of peak $\mathrm{Ca}^{2+}$ currents for the same cell illustrated in $A$. Note the two separate inflections of the inactivating current corresponding to the T-type $(-50 \mathrm{mV})$ and $\mathrm{HVA}_{I}(-10 \mathrm{mV}) \mathrm{Ca}^{2+}$ currents.

\section{Pharmacological characteristics of $\mathrm{Ca}^{2+}$ currents in neostriatal neurons}

The effects of the divalent cations $\mathrm{Mn}^{2+}, \mathrm{Co}^{2+}$, and $\mathrm{Cd}^{2+}$, which are known $\mathrm{Ca}$ channel blockers, were determined on neostriatal $\mathrm{Ca}^{2+}$ currents. In three neurons that had both high-threshold and $\mathrm{T}$-type $\mathrm{Ca}^{2+}$ currents, both currents were blocked to a similar degree by $\mathrm{Mn}^{2+}$ (Fig. 7). Thus, $1 \mathrm{mM} \mathrm{Mn}^{2+}$ decreased $\mathrm{Ca}^{2+}$ currents by about $50 \%$ (high-threshold currents decreased $54 \pm$

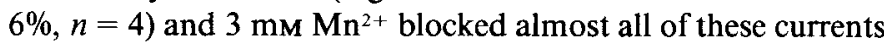
(high-threshold $\mathrm{Ca}^{2+}$ currents decreased by $93 \pm 3 \%, n=7$ ). This effect was largely reversible and was accompanicd by a shift of about $10 \mathrm{mV}$ in the positive direction of the voltage eliciting the peak current. $\mathrm{Co}^{2+}$ also decreased both high- and low-threshold $\mathrm{Ca}^{2+}$ currents at $1 \mathrm{~mm}$ and $2 \mathrm{~mm}$ concentrations ( $n=3$; data not shown), with the block virtually complete at 3 mM $(n=3$, data not shown). The higher concentration ( $3 \mathrm{~mm})$ of $\mathrm{Co}^{2+}$ also appeared detrimental to cell viability as judged by 

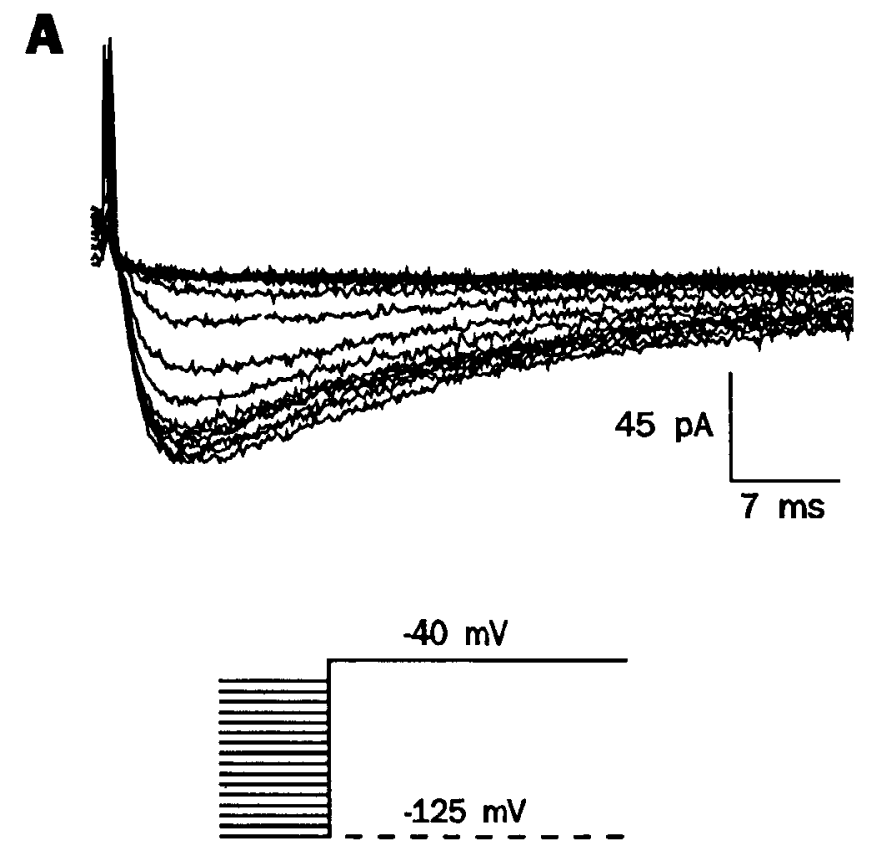

B

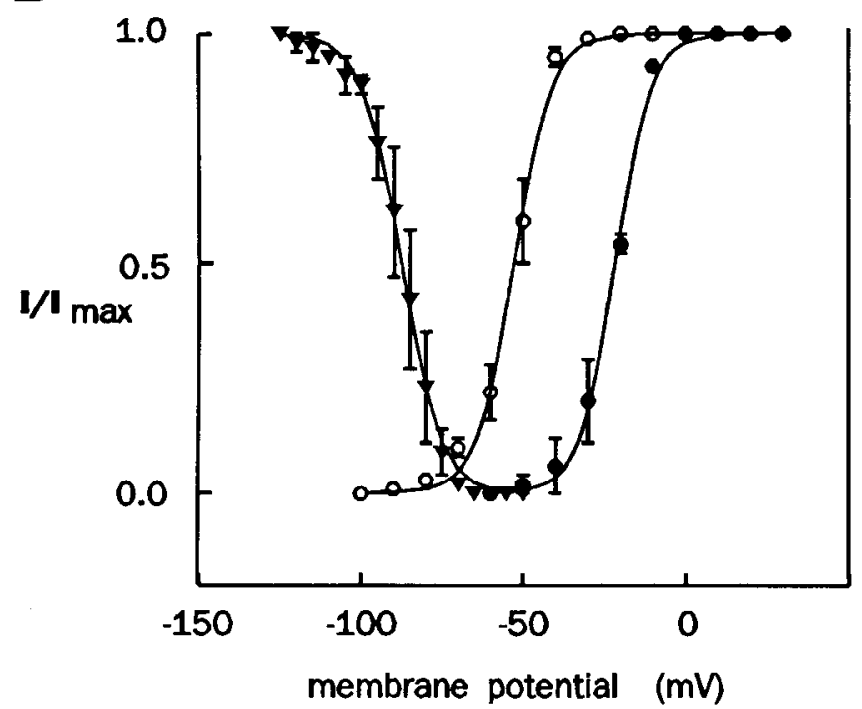

Figure 5. Voltage dependence of inactivation of the T-type $\mathrm{Ca}^{2+}$ current and of activation of the T-type and $\mathrm{HVA}_{S} \mathrm{Ca}^{2+}$ currents. $A$, Current recordings from a representative experiment to determine steady-state inactivation of the $\mathrm{T}$-type $\mathrm{Ca}^{2}+$ current using the voltage protocol illustrated below the current traces. The holding potential was held for $3 \mathrm{sec}$ at values that varied between $-125 \mathrm{mV}$ and $-50 \mathrm{mV}$ prior to evoking the T-type $\mathrm{Ca}^{2+}$ current with a test potential of $-40 \mathrm{mV}$. $B$, Plot of inactivation of the T-type $\mathrm{Ca}^{2+}$ current $(\nabla, n=4$ neurons), activation of the T-type $\mathrm{Ca}^{2+}$ current $(\mathrm{O}, n=7$ neurons) and activation of the $\mathrm{HVA}_{S} \mathrm{Ca}^{2+}$ current (O, $n=7$ neurons). Values are mean $\pm \mathrm{SEM}$ of normalized data with fractional current plotted as $I / I_{\max }$. The voltage dependence of activation of the T-type $\mathrm{Ca}^{2+}$ current was determined from a holding potential of $-100 \mathrm{mV}$ with steps to test potentials between $-90 \mathrm{mV}$ and $0 \mathrm{mV}$ and the inactivating current was isolated as described in the Figure 3 caption. The voltage dependence of activation of the $\mathrm{HVA}_{s} \mathrm{Ca}^{2+}$ current was obtained from a holding potential of $-60 \mathrm{mV}$ with steps to test potentials between $-50 \mathrm{mV}$ and +30 $\mathrm{mV}$. The data points were fit by Boltzmann relations (see text). The voltage at which half-maximal inactivation of the T-type $\mathrm{Ca}^{2+}$ current occurred was $-87.6 \mathrm{mV}$, and the slope of the equation $(k)$ was -6.1 $\mathrm{mV}$. The voltages at which half-maximal activation of the T-type and. $\mathrm{HVA}_{s} \mathrm{Ca}^{2+}$ currents occurred were $-52.8 \mathrm{mV}$ and $-21.6 \mathrm{mV}$, and the slopes $(k)$ were 5.8 and $5.6 \mathrm{mV}$, respectively.
A
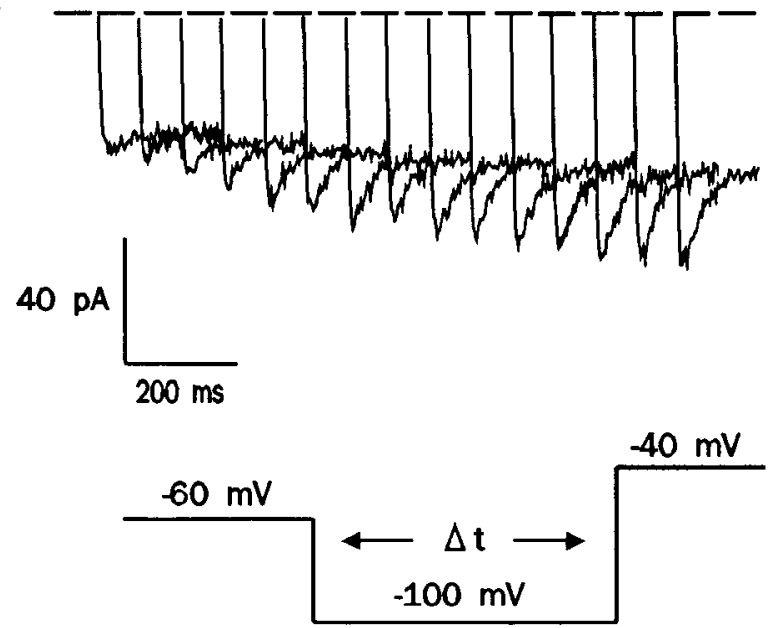

$\mathbf{B}$

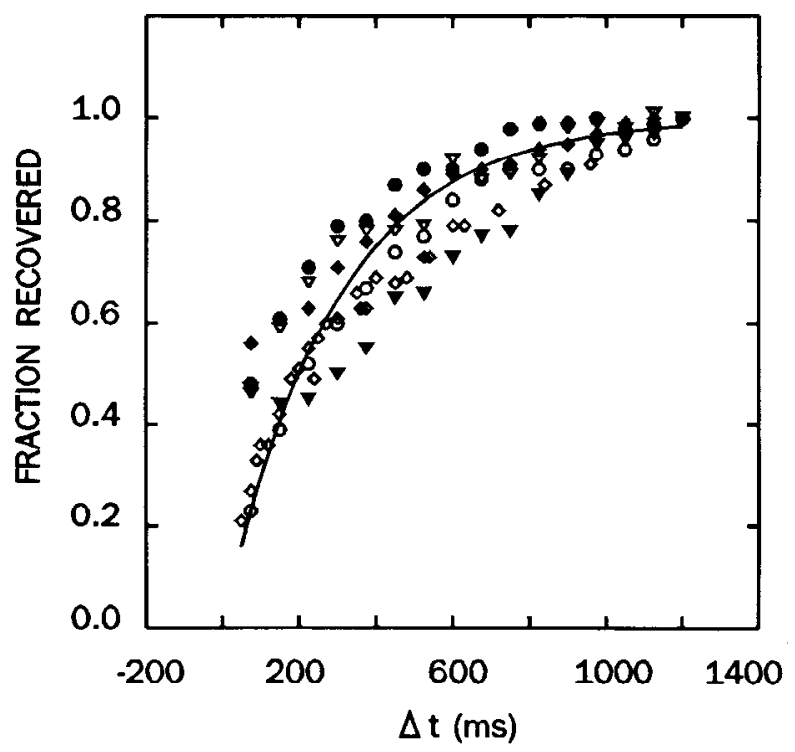

Figure 6. Time course of recovery from inactivation of the T-type $\mathrm{Ca}^{2+}$ current. $A$, Current recordings from a representative experiment using the voltage protocol illustrated below the current recordings. The holding potential was stepped from $-60 \mathrm{mV}$ to $-100 \mathrm{mV}$ for variable durations between 50 and $1200 \mathrm{msec}(\Delta t)$ before T-type $\mathrm{Ca}^{2+}$ currents were evoked by a step to $-40 \mathrm{mV}$. Currents were not leak subtracted. The amplitude of the T-type $\mathrm{Ca}^{2+}$ current was determined by subtracting the maximum current from the steady-state current at the end of the step to $-40 \mathrm{mV}$. $B$, The fractional recovery of the T-type $\mathrm{Ca}^{2+}$ current is plotted with respect to time. Symbols represent individual data points from six different neurons, with each type of symbol representing a different experiment. The solid line is a single exponential with $\gamma=288$ msec.

an increase in the holding current. In contrast to the nonspecific block by $\mathrm{Mn}^{2+}$ and $\mathrm{Co}^{2+}$ of high-threshold and T-type $\mathrm{Ca}^{2+}$ currents, a low concentration of $\mathrm{Cd}^{2+}(25 \mu \mathrm{M})$ reversibly blocked high-threshold $\mathrm{Ca}^{2+}$ currents by $79 \pm 3 \%(n=14)$ while leaving T-type $\mathrm{Ca}^{2+}$ channels largely unaffected (decreased $14 \pm 5 \%, n$ $=7$ ). A representative experiment illustrating the differential effect of $25 \mu \mathrm{M} \mathrm{Cd}^{2+}$ on high-thrcshold $\mathrm{Ca}^{2+}$ current and on T-type $\mathrm{Ca}^{2+}$ current is shown in Figure 8 .

The organic $\mathrm{Ca}$ channel blocker verapamil also preferentially blocked high-threshold $\mathrm{Ca}^{2+}$ currents as compared to T-type $\mathrm{Ca}^{2+}$ currents (Fig. 9) and this effect was partially reversible. At 
A

$\mathbf{B}$
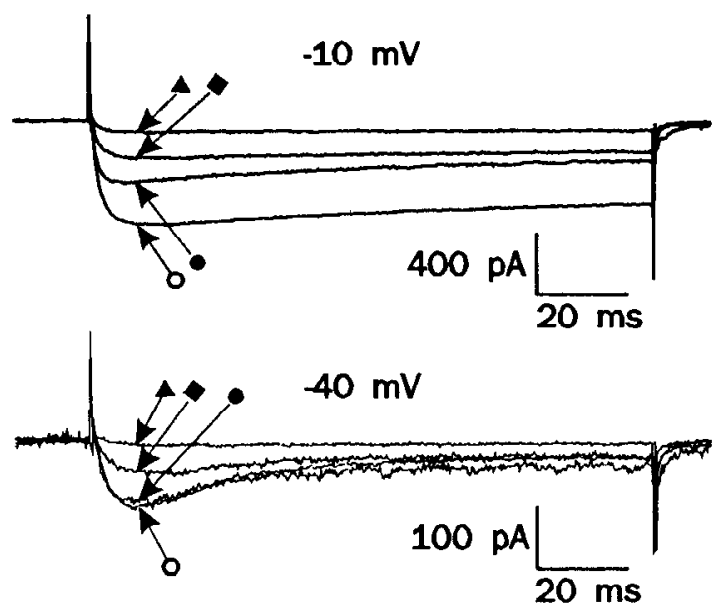

C

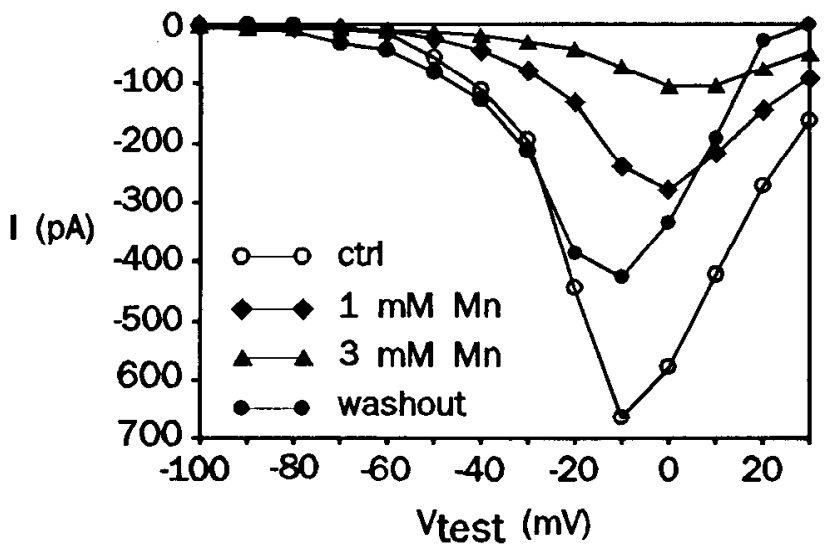

Figure 7. Effect of $\mathrm{Mn}^{2+}$ on high-threshold and T-type $\mathrm{Ca}^{2+}$ currents. $A$ and $B$, Representative current recordings obtained by stepping from a holding potential of $-100 \mathrm{mV}$ to the indicated test potentials to illustrate the effect of $\mathrm{Mn}^{2+}$ on high-threshold $(A)$ and T-type $(B) \mathrm{Ca}^{2+}$ currents. The cell was sequentially exposed to control medium $(O), 1$ $\mathrm{mm} \mathrm{Mn}^{2+}(\diamond), 3 \mathrm{mM} \mathrm{Mn}^{2+}(\boldsymbol{\Delta})$, and control medium (washout, $\bullet$ ). Note the fourfold difference in scale between $A$ and $B$. $C$, Current-voltage relationship of peak $\mathrm{Ca}^{2+}$ currents obtained under each of these conditions. Both high-threshold and T-type $\mathrm{Ca}^{2+}$ currents are blocked by $\mathrm{Mn}^{2+}$. Recovery of the T-type $\mathrm{Ca}^{2+}$ current is virtually complete following washout, whereas the high-threshold $\mathrm{Ca}^{2+}$ currents do not fully recover.

verapamil concentrations of $50 \mu \mathrm{M}$ and $150 \mu \mathrm{M}$, the maximum high-threshold $\mathrm{Ca}^{2+}$ current was depressed by $65 \pm 5 \%(n=4)$ and $93 \pm 3 \%(n=4)$, respectively. In three of three neurons, verapamil also slightly decreased T-type $\mathrm{Ca}^{2}$ currents as had been reported previously (Boll and Lux, 1985). Ethosuximide, which blocks T-type $\mathrm{Ca}^{2+}$ currents in thalamic neurons (Coulter et al., 1989a), did not appreciably block T-type $\mathrm{Ca}^{2+}$ currents in neostriatal neurons at concentrations of $350 \mu \mathrm{M}$ or $700 \mu \mathrm{M}$ ( $n=4$; data not shown).

Dihydropyridines such as nimodipine modulate "L-type" $\mathrm{Ca}$ channels (Nowycky et al., 1985; McCleskey et al., 1987; Aosaki and Kasai, 1989), which correspond in their kinetics to the current we refer to here as $\mathrm{HVA}_{s}$. Therefore, we examined the effects of nimodipine on high-threshold $\mathrm{Ca}^{2+}$ currents in neostriatal neurons to determine whether the $\mathrm{HVA}_{s}$ currents in these cells correspond pharmacologically to "L-type" $\mathrm{Ca}^{2+}$ currents described in other neurons (Fox et al., 1987). In the majority
A

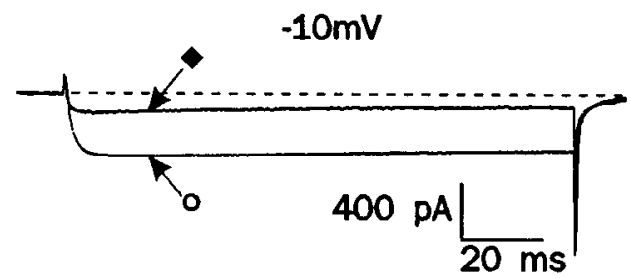

B

$-40 \mathrm{mV}$

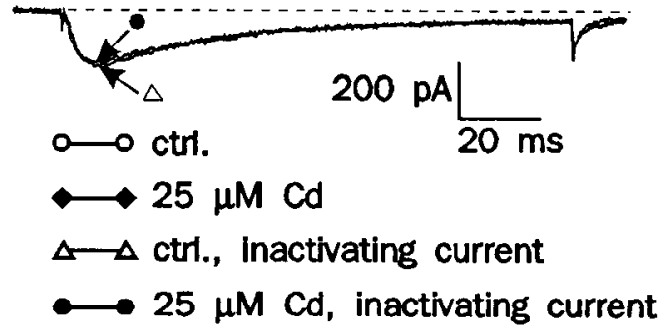

C

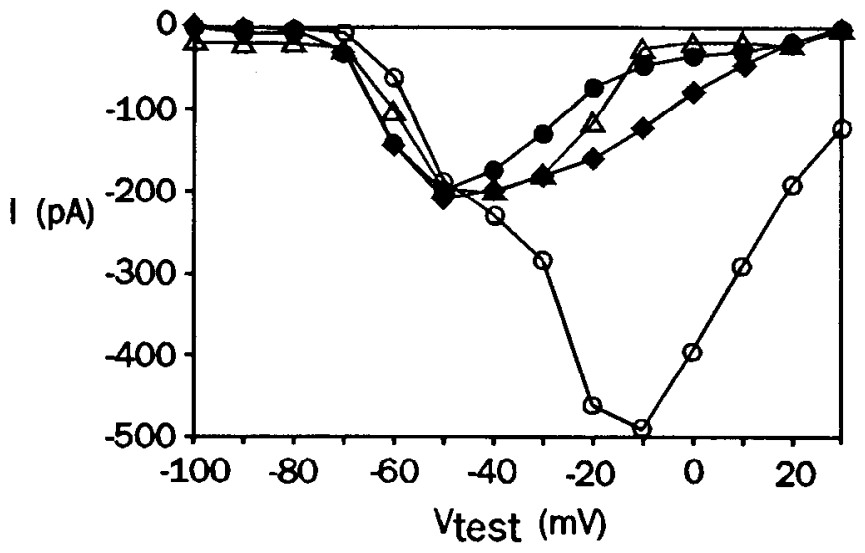

Figure 8. Effect of $\mathrm{Cd}^{2+}$ on high-threshold and T-type $\mathrm{Ca}^{2+}$ currents. $A$, Representative high-threshold $\mathrm{Ca}^{2+}$ current recordings obtained by stepping from a holding potential of $-100 \mathrm{mV}$ to the test potential of $-10 \mathrm{mV}$ in the absence $(O)$ and presence $(\diamond)$ of $\mathrm{Cd}^{2+}(25 \mu \mathrm{M}) . B$, The T-type $\mathrm{Ca}^{2+}$ current (inactivating current) is shown at the test potential

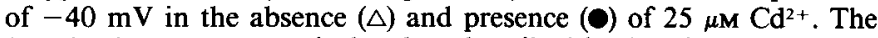
inactivating current was isolated as described in the Figure 3 caption. Note the difference in scale between $A$ and $B$. The broken line indicates 0 current. $C$, Current-voltage relationships of peak $\mathrm{Ca}^{2+}$ currents from the same cell as in $A$ and $B . \mathrm{Cd}^{2+}(25 \mu \mathrm{M})$ markedly diminishes the high-threshold $\mathrm{Ca}^{2+}$ currents while leaving the $\mathrm{T}$-type $\mathrm{Ca}^{2+}$ current virtually unaltered.

of neurons (five of seven), nimodipine (10 $\mu \mathrm{M})$ did not affect high- or low-threshold $\mathrm{Ca}^{2+}$ currents elicited from a holding potential of $-100 \mathrm{mV}$, consistent with the reported voltage dependence of inhibition by dihydropyridines (Bean, 1984; Sanguinetti and Kass, 1984). When neurons were held at $-40 \mathrm{mV}$ and the $\mathrm{HVA}_{s}$ current was evoked in isolation with a step to $-10 \mathrm{mV}$ every $10 \mathrm{sec}$, nimodipine had a small blocking effect on this current (Fig. 10A,B), decreasing it by $17 \pm 5 \%$ (mean \pm SEM) in five of six neurons tested. Thus, only a small com-

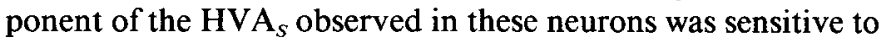
blockade by nimodipine.

The dihydropyridine-insensitive, $\omega$-conotoxin-sensitive component of the high-threshold $\mathrm{Ca}^{2+}$ current has been called the "N-type" Ca channel by Tsien and colleagues (Tsien et al., 1988). The $\omega$-conotoxin sensitivity of neostriatal high-threshold 

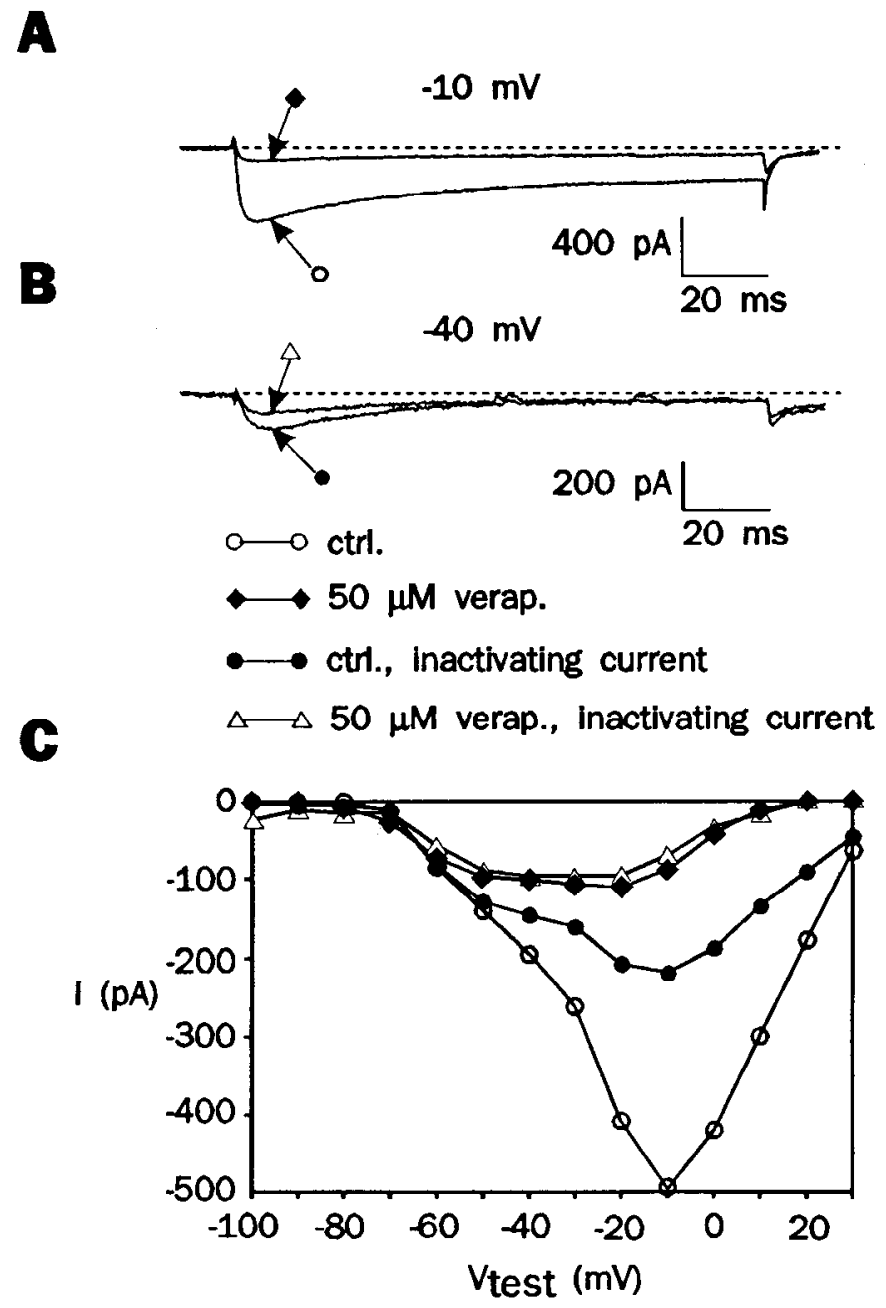

Figure 9. Effect of verapamil on high-threshold and T-type $\mathrm{Ca}^{2+}$ currents. $A$, Representative high-threshold $\mathrm{Ca}^{2+}$ current recordings obtained by stepping from a holding potential of $-100 \mathrm{mV}$ to the test potential of $-10 \mathrm{mV}$ in the absence $(O)$ and presence $(\$)$ of verapamil $(50 \mu \mathrm{M}) . B$, The T-type $\mathrm{Ca}^{2+}$ current (inactivating current) is shown at the test potential of $-40 \mathrm{mV}$ in the absence $(\bullet)$ and presence $(\triangle)$ of 50 $\mu \mathrm{M}$ verapamil. The inactivating current was isolated as described in the Figure 3 caption. Note the difference in scale between $A$ and $B$. The broken line indicates 0 current. $C$, Current-voltage relationships of peak $\mathrm{Ca}^{2+}$ currents from the same cell as in $A$ and $B$. Verapamil $(50 \mu \mathrm{M})$ blocks high-threshold $\mathrm{Ca}^{2+}$ currents while $\mathrm{T}$-type $\mathrm{Ca}^{2+}$ currents are decreased by about $40 \%$. Note the prominent inactivating component (HVA,) of the high-threshold $\mathrm{Ca}^{2+}$ current in this cell.

$\mathrm{Ca}^{2+}$ currents evoked from two different holding potentials was determined. When neurons were held at $-100 \mathrm{mV}$ and combined $\mathrm{HVA}_{S}$ and $\mathrm{HVA}_{I} \mathrm{Ca}^{2+}$ currents were evoked by a step to $-10 \mathrm{mV}, \omega$-conotoxin decreased the peak current by $29 \pm 5 \%$ (mean $\pm \mathrm{SEM}$, three of four neurons; Fig. 10C,D). When the $\mathrm{HVA}_{S} \mathrm{Ca}^{2+}$ current was isolated by holding the neuron at -40 $\mathrm{mV}$ and stepping to $-10 \mathrm{mV}, \omega$-conotoxin still blocked $\mathrm{HVA}_{S}$ $\mathrm{Ca}^{2+}$ current by $39 \pm 8 \%$ (mean \pm SEM, three of three neurons; Fig. $10 A, B$ ), indicating that the inhibitory action of $\omega$-conotoxin in neostriatal neurons was not selective for the $\mathrm{HVA}_{I}$ current.

\section{Localization of $\mathrm{Ca}^{2+}$ currents to the soma or dendrites of} neostriatal neurons

The spatial distribution of Ca channels on the cell surface may be critically important for the processing and transmission of electrical signals in neurons (Llinas, 1988). To determine if there is a differential distribution of high-threshold and low-threshold Ca channels on the soma versus the proximal dendrites of neostriatal neurons, we observed the changes in $\left[\mathrm{Ca}^{2+}\right]_{i}$ as determined by fura- 2 fluorescence imaging in the soma and proximal dendrites of neurons acutely isolated from neostriatum. Distal dendrites were not present following the acute isolation procedure. Neurons were depolarized in the presence and absence of $25 \mu \mathrm{M} \mathrm{Cd}{ }^{2+}$ to block the high-threshold $\mathrm{Ca}^{2+}$ conductances, while leaving low-threshold $\mathrm{Ca}^{2+}$ condùctances relatively intact. Depolarization of neostriatal neurons with $50 \mathrm{~mm}$ $\mathrm{KCl}$ resulted in an increase in $\left[\mathrm{Ca}^{2+}\right]_{i}$ in both the soma and dendrites of these neurons (Figs. 11, 12). This $\left[\mathrm{Ca}^{2+}\right]_{i}$ increase was reversible upon washout of the $50 \mathrm{~mm} \mathrm{KCl}$-containing solution. Application of $\mathrm{Cd}^{2+}$ alone did not change the baseline fluorescence ratios. A second $2 \mathrm{~min} \mathrm{KCl}$ depolarization in the

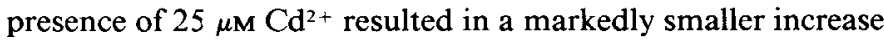
in $\mathrm{Ca}^{2+}$ in both the soma and dendrites, suggesting that highthreshold Ca channels are present in both the soma and proximal dendrites of neostriatal neurons. The remaining $\mathrm{Ca}^{2+}$ increase in the somata and dendrites could be due to the presence of l-type $\mathrm{Ca}^{2+}$ channels that are virtually unaffected by $25 \mu \mathrm{M}$ $\mathrm{Cd}^{2+}$ (Fig. 8). Alternately, it could represent the small proportion (approximatcly $21 \%$ ) of high-threshold Ca channels that are not affected by $25 \mu \mathrm{M} \mathrm{Cd}^{2+}$. A third depolarization with $50 \mathrm{mM} \mathrm{KCl}$ following washout of $\mathrm{Cd}^{2+}$ resulted in a much greater increase in $\left[\mathrm{Ca}^{2+}\right]_{i}$ than was seen in the presence of $\mathrm{Cd}^{2+}$, illustrating the reversibility of the block. Some reduction of the response to a third consecutive depolarization was evident in most neurons. Figures 11 and 12 show the changes in $\left[\mathrm{Ca}^{2+}\right]_{i}$ and the time course, respectively, from two separate neurons. Similar changes were seen in two other neurons.

\section{Discussion}

\section{Kinetic separation of $\mathrm{Ca}^{2+}$ current subtypes and their} distribution in the neostriatum

These data show that there are multiple types of $\mathrm{Ca}^{2+}$ currents in neostriatal neurons. T-type $\mathrm{Ca}^{2+}$ currents could be clearly separated from high-threshold $\mathrm{Ca}^{2+}$ currents according to kinctic criteria. Thus, similar to $\mathrm{T}$-type $\mathrm{Ca}^{2+}$ currents from other brain regions (Yaari et al., 1987; Coulter et al., 1989b; Hernández-Cruz and Pape, 1989; Fraser and MacVicar, 1991; Mogul and Fox, 1991; Takahashi et al., 1991), neostriatal T-type $\mathrm{Ca}^{2+}$ currents were activated at relatively hyperpolarized potentials, inactivated within tens of milliseconds during a depolarizing pulse, and exhibited steady-state inactivation that was half-maximal at $-88 \mathrm{mV}$. T-lype $\mathrm{Ca}^{2}$ । currents were found in $40 \%$ of neostriatal neurons. When present, they represented a small fraction of the total $\mathrm{Ca}^{2+}$ current, being only $21 \%, 8 \%$, and $9 \%$ as large as the high-threshold $\mathrm{Ca}^{2+}$ current in small-, medium-, and large-sized neostriatal neurons, respectively.

In the present study, high-threshold $\mathrm{Ca}^{2+}$ currents were divided into two subtypes according to the presence or absence of steady-state inactivation. Thus, $\mathrm{Ca}^{2+}$ currents that were unaffected by a change in holding potential from $-100 \mathrm{mV}$ to -60 $\mathrm{mV}$ were called $\mathrm{HV} \Lambda_{S} \mathrm{Ca}^{2+}$ currents whereas those that inactivated following a similar change in holding potential were called $\mathrm{HVA}, \mathrm{Ca}^{2+}$ currents. However, this subdivision of highthreshold currents may not correlate with distinct $\mathrm{Ca}$ channel types because (1) $\mathrm{HVA}_{I} \mathrm{Ca}^{2+}$ currents appeared to belong to a heterogeneous group in that they exhibited highly variable degrees of inactivation during a $150 \mathrm{msec}$ depolarizing pulse (but 


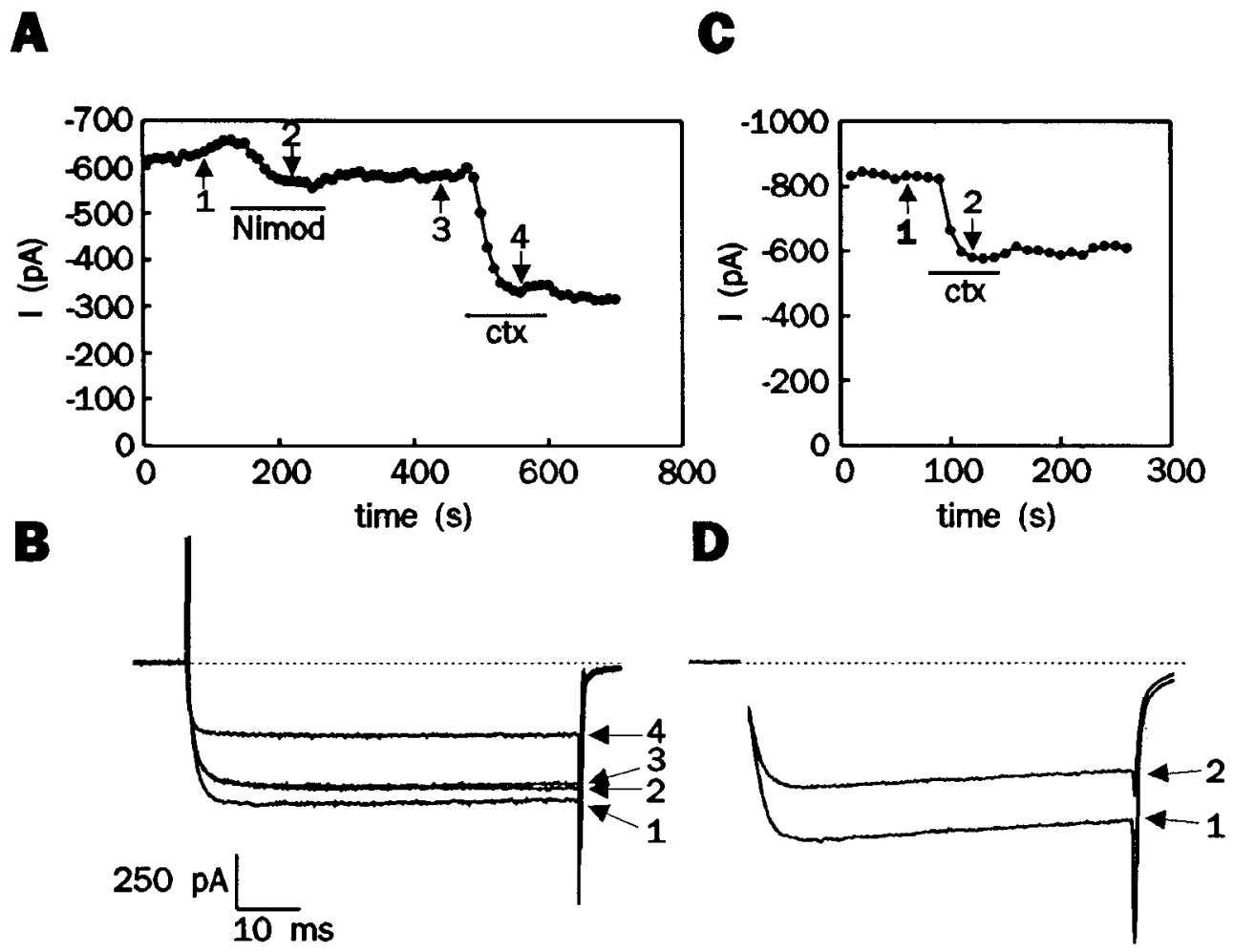

Figure 10. Time course of block of high-threshold $\mathrm{Ca}^{2+}$ currents by nimodipine and $\omega$-conotoxin. $A$, Representative plot of $\mathrm{Ca}^{2+}$ current versus time illustrating the effect of nimodipine (Nimod) and $\omega$-conotoxin (ctx) on $\mathrm{HVA}_{s} \mathrm{Ca}^{2+}$ currents. The cell was depolarized to $-10 \mathrm{mV}$ every 10 sec from a holding potential of $-40 \mathrm{mV}$. Superfusion with medium containing $10 \mu \mathrm{M}$ nimodipine resulted in a slight decrease of the high-threshold $\mathrm{Ca}^{2+}$ current. The subsequent addition of $5 \mu \mathrm{M} \omega$-conotoxin to the superfusing medium resulted in a much larger decrease in $\mathrm{Ca}^{2+}$ current. $\mathrm{Horizontal}$ bars indicate the time of drug application. The numbered arrows indicate traces illustrated in $B$. $B$, Current recordings from the experiment illustrated in $A$. Each trace is an average of four consecutive recordings with the first one corresponding to the numbered arrow. $C$, Plot of $\mathrm{Ca}^{2+}$ current versus time illustrating the effect of $\omega$-conotoxin on combined $\mathrm{HVA}_{1}$ and $\mathrm{HVA}_{s} \mathrm{Ca}^{2+}$ currents. The cell was depolarized to $-10 \mathrm{mV}$ every 10 sec from a holding potential of - $100 \mathrm{mV}$ and supcrfused with $5 \mu \mathrm{M} \omega$-conotoxin at the time indicated by the horizontal bar. The numbered arrows indicate traces illustrated in $D$. $D$, Current recordings from the experiment illustrated in $C$. Each trace is an average of three consecutive recordings, with the first one corresponding to the numbered arrow. For illustration, the first $1 \mathrm{msec}$ of the capacitance transient was omitted from the current recording.

see Plummer and Hess, 1991), and (2) pharmacological studies with nimodipine and $\omega$-conotoxin did not support this subdivision of high-threshold $\mathrm{Ca}^{2+}$ currents (see below). Nonetheless, this subdivision provides information on the percentage of $\mathrm{Ca}^{2+}$ current that would be available for activation at a given membrane potential. Virtually all neostriatal neurons exhibited $\mathrm{HVA}_{S}$ $\mathrm{Ca}^{2+}$ currents, and $70 \%$ of neostriatal neurons exhibited $\mathrm{HVA}_{I}$ $\mathrm{Ca}^{2+}$ currents. However, the $\mathrm{HVA}, \mathrm{Ca}^{2+}$ current represented only $23 \%$ of the total high-threshold $\mathrm{Ca}^{2+}$ current. The resting membrane potential of neostriatal neurons in vivo has been found to fluctuate between $-75 \mathrm{mV}$ and $-55 \mathrm{mV}$ (Wilson and Groves, 1981; Wilson et al., 1983) with an average resting potential of $-64 \pm 4 \mathrm{mV}$ reported in a recent in vivo study of 110 neostriatal neurons (Calabresi et al., 1990). Thus, it appears that, at the resting potential of neostriatal neurons in vivo, most of the high-threshold $\mathrm{Ca}^{2+}$ current in neostriatal neurons would be expected to be available for activation and could thus play a role in determining firing characteristics of these neurons.

\section{Pharmacological separation of $\mathrm{Ca}^{2+}$ current subtypes in the} neostriatum

T-type and high-threshold $\mathrm{Ca}^{2+}$ currents were blocked to a similar degree by low millimolar concentrations of $\mathrm{Mn}^{2+}$ and $\mathrm{Co}^{2+}$. However, T-type $\mathrm{Ca}^{2+}$ currents could be distinguished phar- macologically from high-threshold $\mathrm{Ca}^{2+}$ currents by their insensitivity to $25 \mu \mathrm{M} \mathrm{Cd}{ }^{2+}$. Moreover, T-type $\mathrm{Ca}^{2+}$ currents were less sensitive to the $\mathrm{Ca}$ channel blocker verapamil than were high-threshold $\mathrm{Ca}^{2+}$ currents. These differences in sensitivity of high- and low-threshold $\mathrm{Ca}^{2+}$ currents to $\mathrm{Cd}^{2+}$ (Fox et al., 1987; Narahashi et al., 1987; Akaike et al., 1989; Mogul and Fox, 1991) and verapamil (Boll and Lux, 1985; Fedulova et al., 1985) have been observed in other cell types. In addition, some sensitivity of low-threshold $\mathrm{Ca}^{2+}$ currents to verapamil has been reported previously (Boll and Lux, 1985; Akaike et al., 1989). The anticonvulsant ethosuximide, which blocks thalamic lowthreshold $\mathrm{Ca}^{2+}$ currents (Coulter et al., 1989a), did not affect neostriatal T-type $\mathrm{Ca}^{2+}$ currents. Differences in sensitivity of low-threshold $\mathrm{Ca}^{2+}$ currents to ethosuximide (Thompson and Wong, 1991) and another T-type $\mathrm{Ca}^{2+}$ current antagonist, amiloride, have been observed previously (Tang et al., 1988; Carbone et al., 1990), and such discrepancies might be explained by the existence of multiple types of low-threshold $\mathrm{Ca}^{2+}$ channels (Carbone et al., 1990; Huguenard and Prince, 1991).

There is general agreement that dihydropyridines affect primarily the "L-type" Ca channels as described by Tsien and colleagues (Fox et al., 1987; McCleskey et al., 1987; Tsien et al., 1988; Aosaki and Kasai, 1989; but see Akaike et al., 1989). However, dihydropyridine-induced blockade of non-"L-type" 

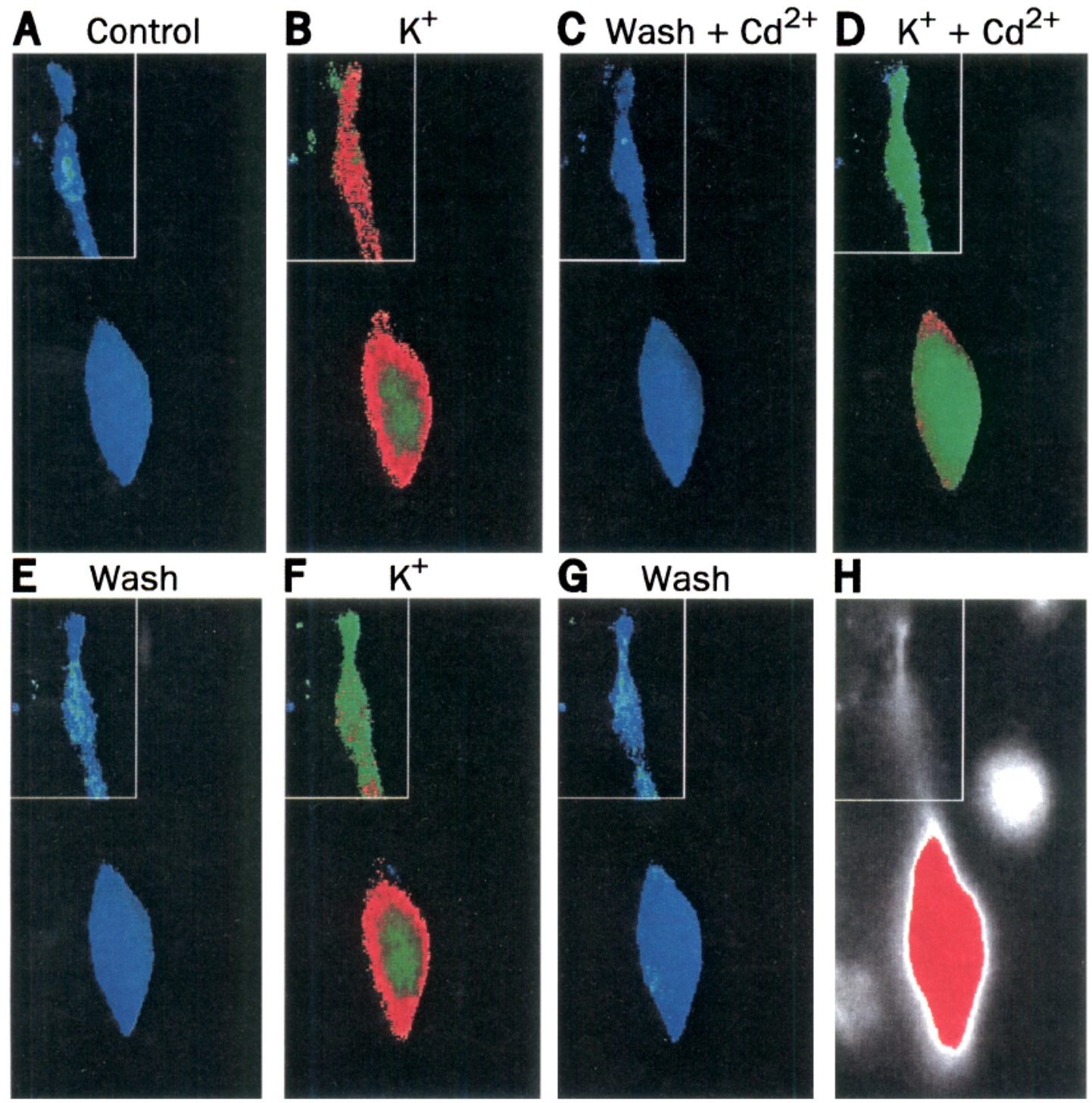
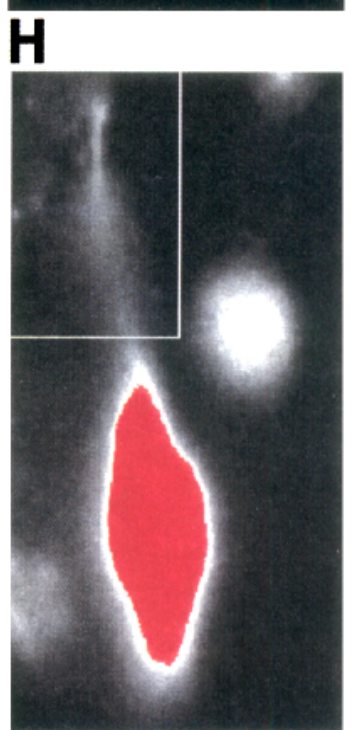
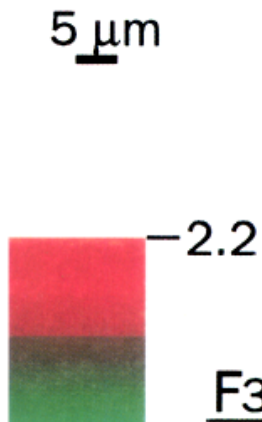

F340 F380

Figure 11. Fura-2 fluorescence images show a $\mathrm{Cd}^{2+}$-sensitive rise in $\left[\mathrm{Ca}^{2+}\right]_{i}$ in the somata and processes of striatal neurons caused by depolarization. Computer-processed images are illustrated from a representative experiment. Changes in the $F_{340}: F_{380}$ ratio, corresponding to relative changes in $\left[\mathrm{Ca}^{2+}\right]_{i}$, are represented by changes in pixel color. Every $45 \mathrm{sec}$, fluorescence images (averages of 8 frames at $30 \mathrm{~Hz}$ ) were taken at two gain settings on the image intensifier: one that allowed visualization of the soma and another higher gain setting that allowed visualization of the thinner, fainter processes (shown as insets superimposed on the image of the soma taken at the higher gain setting). Representative images from an experiment are shown before $(A)$ and during $(B)$ depolarization by $50 \mathrm{~mm} \mathrm{KCl}$, which resulted in a rise in $\left[\mathrm{Ca}^{2+}\right]_{i}$. After washout of $\mathrm{KCl}$, the cell was superfused with $25 \mu \mathrm{M} \mathrm{Cd}{ }^{2+}(C)$, and then depolarized in the presence of $\mathrm{Cd}^{2+}(D)$. Note the marked decrease in $\mathrm{Ca}^{2+}$ entry in both the soma and processes in the presence of $\mathrm{Cd}^{2+}$. Recovery $(E)$ and repeated exposure to $50 \mathrm{mM} \mathrm{KCl}(F)$ are also shown. The fura-2 stain image at $360 \mathrm{~nm}$ shown in $H$ (in red and white) illustrates how, when the gain was set for visualization of the processes, the readings obtained for the soma (in red) were saturated. It also illustrates the area in the top left corner from which the insets were taken.

neuronal Ca channels (Akaike et al., 1989; Sayer et al., 1990) as well as the failure of dihydropyridines to block some highthreshold noninactivating $\mathrm{Ca}^{2+}$ currents in the CNS (Leonard et al., 1987; Llinás et al., 1989; Mogul and Fox, 1991; Regan et al., 1991) have recently been reported. Our results indicate that nimodipine had only minimal effects on high-threshold $\mathrm{Ca}^{2+}$ currents in neostriatal neurons even when $\mathrm{Ca}^{2+}$ currents were elicited from a depolarized holding potential $(-40 \mathrm{mV})$ at which the antagonist is most effective (Bean, 1984; Sanguinetti and Kass, 1984) and at which inactivating ("N-type") components of the high-threshold $\mathrm{Ca}^{2+}$ current would be eliminated. These observations suggest that classical "L-type" Ca channels carry only a small component of the $\mathrm{Ca}^{2+}$ current in neostriatal neurons. This is consistent with observations that dihydropyridine-sensitive $\mathrm{Ca}$ channels contribute a much smaller fraction of the total $\mathrm{Ca}^{2+}$ currents in neurons (Bean, 1989; Plummer et al., 1989; Regan et al., 1991) than in cardiac or smooth muscle (reviewed by Bean, 1989).

$\omega$-Conotoxin blocked $29 \%$ and 39\% of high-threshold $\mathrm{Ca}^{2+}$ currents elicited from hyperpolarized $(-100 \mathrm{mV})$ and depolarized $(-40 \mathrm{mV})$ holding potentials, respectively. In the initial description of "N-type" Ca channels, steady-state inactivation and rapid inactivation during strong depolarizations were thought to be characteristic of this channel (Fox et al., 1987; Tsien et al., 1988). However, the observation that $\omega$-conotoxin blocked what appeared, by kinetic criteria, to be "L-type" Ca channels 
led to controversy regarding whether $\omega$-conotoxin blocks only "N-type" Ca channels (Kasai et al., 1987) or both "N-type" and "L-type" Ca channels (McCleskey et al., 1987). More recent single-channel (Aosaki and Kasai, 1989; Plummer et al., 1989; Plummer and Hess, 1991) and whole-cell studies (Carbone et al., 1990) of $\mathrm{Ca}^{2+}$ currents strongly suggest that dihydropyridineinsensitive, $\omega$-conotoxin-sensitive channels may contribute both inactivating and sustained components of high-threshold $\mathrm{Ca}^{2}$ i currents and that $\omega$-conotoxin-sensitive currents can be elicited from depolarized holding potentials (reviewed by Sher and Clementi, 1991). It appears that "N-type" $\mathrm{Ca}$ channels cannot be distinguished from "L-type" $\mathrm{Ca}$ channels by their whole-cell kinetics (Swandulla et al., 1991). Indeed, it has been proposed that "N-type" Ca channels be redefined as those channels that are sensitive to $\omega$-conotoxin (Aosaki and Kasai, 1989; Plummer et al., 1989; Carbone et al., 1990). According to this redefinition, about $30-40 \%$ of neostriatal high-threshold $\mathrm{Ca}^{2+}$ currents are carried through $\omega$-conotoxin-sensitive " $N$-type" Ca channels.

In the present study, nimodipine and $\omega$-conotoxin were applied at concentrations that have been shown to effect maximal inhibition of high-threshold $\mathrm{Ca}^{2+}$ currents in central neurons (Mogul and Fox, 1991; Penington et al., 1991; Regan et al., 1991). Nonetheless, a large proportion of the high-threshold $\mathrm{Ca}^{2+}$ current in neostriatal neurons is clearly insensitive to block by either of these antagonists. Components of $\mathrm{Ca}^{2+}$ currents that are insensitive to dihydropyridines and nimodipine have also been reported in other brain regions including neocortex, hippocampus, and cerebellum (Sayer et al., 1990; Mogul and Fox, 1991; Regan et al., 1991) and in Xenopus oocytes injected with rat brain mRNA (Leonard et al., 1987). In cerebellum the proportion of high-threshold $\mathrm{Ca}^{2+}$ current that is resistant to these blockers is particularly large (Regan et al., 1991), and it has been proposed that high-threshold $\mathrm{Ca}^{2+}$ currents in this region may be carried by a distinct Ca channel, the "P-channel" (Llinás et al., 1989), which is blocked by funnel-web spider toxin (Lin et al., 1990). It is possible that the nimodipine- and $\omega$-conotoxininsensitive high-threshold $\mathrm{Ca}^{2+}$ currents in the neostriatum are of the "P-channel" type. However, a recent immunohistochemical study using an antibody against "P-type" Ca channels suggests that the density of P-type channels is low in the striatum as compared other brain regions (Hillman et al., 1991). Alternatively, it is possible that the nimodipine- and $\omega$-conotoxininsensitive high-threshold $\mathrm{Ca}^{2+}$ currents represent other types of as-yet-unidentified Ca channel in brain (Snutch et al., 1990).

\section{Localization of $\mathrm{Ca}^{2+}$ conductances to the soma or dendrites of neostriatal neurons}

Fura-2 imaging experiments were conducted to localize changes in $\left[\mathrm{Ca}^{2+}\right]$, in neostriatal neurons following depolarization. The results suggest that high-threshold $\mathrm{Ca}^{2+}$ channels are present on both the soma and proximal dendrites of neostriatal neurons and that there is no large nonuniformity of high-threshold $\mathrm{Ca}^{2+}$ conductances in the soma versus the proximal dendrites. This finding contrasts with similar experiments in the hippocampus in which dendritic-somatic $\left[\mathrm{Ca}^{2+}\right]_{i}$ gradients were detected following a $3 \mathrm{~min}$ application of $50 \mathrm{~mm} \mathrm{~K}^{+}$to ncurons acutcly isolated from hippocampal CA1, with a greater rise in $\left[\mathrm{Ca}^{2+}\right]_{i}$ in the dendrites than soma of these neurons (Wadman and Connor, 1992). Similarly, Regehr et al. (1989) have observed that the stimulation-induced fura- $2 \mathrm{Ca}^{2+}$ signal in the somata of hippocampal pyramidal neurons lags behind and is much smaller in amplitude than the $\mathrm{Ca}^{2+}$ signal in the proximal den-

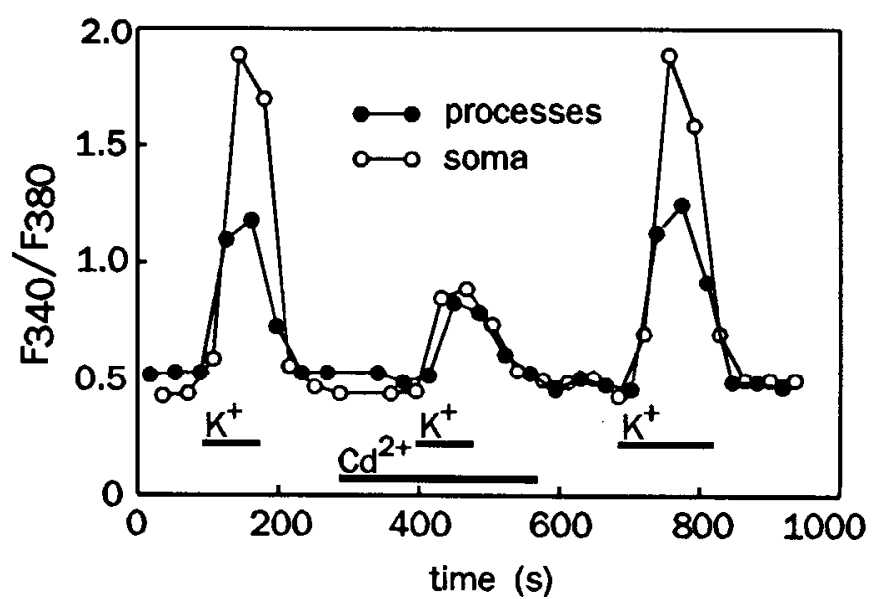

Figure 12. Time course of changes in $\left[\mathrm{Ca}^{2+}\right]_{i}$ in a striatal neuron in the presence and absence of $25 \mu \mathrm{M} \mathrm{Cd}{ }^{2+}$. Changes in the spatial average of the $F_{340}: F_{380}$ fluorescence of the cell soma $(O)$ and processes $(O)$ are plotted against time. The effects of three consecutive depolarizations with $50 \mathrm{~mm} \mathrm{KCl}\left(K^{+}\right)$are shown. The second $\mathrm{KCl}$ application occurred in the presence of $25 \mu \mathrm{M} \mathrm{Cd}^{2+}$, which markedly decreased $\mathrm{Ca}^{2+}$ influx in both the soma and dendrites of striatal neurons. This suggests that high-threshold $\mathrm{Ca}^{2+}$ currents are present in both the somata and dendrites of striatal neurons. Horizontal bars indicate the time of application of $50 \mathrm{mM} \mathrm{KCl}$ or $25 \mu \mathrm{M} \mathrm{Cd}^{2+}$.

drites. Previous studies in the inferior olive (Llinas and Yarom, $1981 \mathrm{~b}$ ), thalamus (Jahnsen and Llinas, 1984), and hippocampus (Yaari et al., 1987) have all yielded the interpretation that highthreshold $\mathrm{Ca}^{2+}$ channels are primarily localized in dendrites whereas low-threshold $\mathrm{Ca}^{2+}$ channels are primarily localized in the cell soma. More recently, however, high-threshold and lowthreshold $\mathrm{Ca}^{2+}$ conductances have been found on all parts of the surface membrane of cultured chick dorsal root ganglion cells (Gottmann et al., 1991). Moreover, antibodies to "L-type" Ca channels have shown that these channels are located on both the soma and proximal dendrites of hippocampal neurons, with the highest density found at the apical dendrites (Westenbroek et al., 1990). It is possible to reconcile the findings of Westenbrock ct al. (1990) with the delayed and diminished $\mathrm{Ca}^{2+}$ entry into the somata of hippocampal neurons observed by Regehr et al. (1989) by recognizing that somata have a much smaller surface-to-volume ratio than dendrites. The observation that the $\mathrm{Ca}^{2+}$ entry into the somata of neostriatal neurons was neither delayed nor smaller than the $\mathrm{Ca}^{2+}$ entry into the proximal dendrites of neostriatal neurons suggests that the density of highthreshold $\mathrm{Ca}^{2+}$ channels on the somata of neostriatal neurons may be greater than the density of these channels on the somata of hippocampal neurons.

\section{Physiological significance of $\mathrm{Ca}^{2+}$ currents in the neostriatum}

The T-type $\mathrm{Ca}^{2+}$ current was present in only $40 \%$ of neostriatal neurons and was small in relation to the total high-threshold $\mathrm{Ca}^{2+}$ current. The observation that $\mathrm{T}$-type $\mathrm{Ca}^{2+}$ currents are generally of small amplitude in neostriatal neurons is consistent with previous findings. Spontancous bursting and oscillatory behavior typical of neurons with prominent $\mathrm{T}$-type $\mathrm{Ca}^{2+}$ currents is absent in neostriatal neurons in vitro (Calabresi et al., 1987; Galarraga et al., 1989), and low levels of spontaneous activity have been reported in these neurons in vivo (Hull et al., 1970; Sugimori et al., 1978). However, a $\mathrm{Ca}^{2+}$-dependent potential resembling a low-threshold $\mathrm{Ca}^{2+}$ spike has been observed 
in neostriatal neurons in TTX- and TEA-containing medium (Calabresi et al., 1987). In the present study, small-sized neostriatal neurons had proportionately more $\mathrm{T}$-type $\mathrm{Ca}^{2+}$ current than medium- and large-sized neostriatal neurons. This suggests that there may be a subpopulation of smaller medium spiny neurons in which the $\mathrm{T}$-type $\mathrm{Ca}^{2+}$ current plays a greater role in determining cell firing properties. Interestingly, $33 \%$ of striatal neurons in vivo exhibit regular spontaneous depolarizing potentials (Calabresi et al., 1990). Although phasic synaptic inputs may be responsible for this bursting activity, it may also result from intrinsic membrane $\mathrm{Ca}^{2+}$ conductances in a subpopulation of neurons.

The T-type $\mathrm{Ca}^{2+}$ current could affect the response of neostriatal neurons to stimuli near the resting membrane potential. There is a significant degree of overlap between the activation and inactivation curves of the T-type $\mathrm{Ca}^{2+}$ current, which suggests that there may be a small steady influx of $\mathrm{Ca}^{2+}$ at some membrane potentials. On depolarization, the inactivation of this steady $\mathrm{Ca}^{2+}$ conductance could contribute to the so-called "anomalous rectification" in the depolarizing direction (increased input resistance during depolarizing current injection; Kita et al., 1985a). This is supported by the finding that "anomalous rectification" in the depolarizing direction is decreased in $\mathrm{Ca}^{2+}$-free medium (Kita et al., 1985a).

High-threshold $\mathrm{Ca}^{2+}$ currents were much more prominent than the $\mathrm{T}$-type $\mathrm{Ca}^{2+}$ current in neostriatal neurons. The importance of high-threshold $\mathrm{Ca}^{2+}$ currents in influencing the firing properties of these neurons has been suggested by current-clamp studies (Kita et al., 1985b; Misgeld et al., 1986; Calabresi et al., 1987, 1990; Cherubini and Lanfumey, 1987; Galarraga et al., 1989). Blockade of $\mathrm{Ca}^{2+}$ currents blocks spontaneous depolarizing potentials and late depolarizations (Calabresi et al., 1990) and results in a decrease in the size of action potentials (Galarraga et al., 1989). Moreover, a $\mathrm{Ca}^{2+}$-activated $\mathrm{K}^{+}$conductance appears to underlie the afterhyperpolarizing potential in neostriatal neurons (Galarraga et al., 1989). Via this mechanism, Ca channel activity may profoundly affect the rate of firing of neostriatal neurons in response to depolarizing stimuli. One of the central functions attributed to $\mathrm{Ca}^{2+}$ currents is their critical role in neurotransmitter relcasc. Both "N-type" and "L-type" $\mathrm{Ca}$ channels have been implicated in this process (reviewed by Bean, 1989), although it is likely that $\mathrm{Ca}^{2+}$ currents at the soma exhibit somewhat different properties from $\mathrm{Ca}^{2+}$ currents at the presynaptic terminals (Lemos and Nowycky, 1989; Stanley, 1991).

Voltage-dependent calcium conductances are an important site for neurotransmitter-mediated modulation of neuronal activity. A number of the major neurotransmitters in the neostriatum (dopamine, $\mathrm{ACh}$, and glutamate) modulate $\mathrm{Ca}^{2+}$ currents in other regions (Toselli and Lux, 1989; Lester and Jahr, 1990; Williams et al., 1990; Chernevskaya et al., 1991; Lledo et al., 1992). Future studies may determine whether the $\mathrm{Ca}^{2+}$ currents in neostriatal neurons are the site of modulation of neostriatal firing properties by neurotransmitters or neuromodulators.

\section{References}

Akaike N, Kostyuk PG, Osipchuk YV (1989) Dihydropyridine-sensitive low-threshold calcium channels in isolated rat hypothalamic neurones. J Physiol (Lond) 412:181-195.

Aosaki T, Kasai H (1989) Characterization of two kinds of highvoltage-activated Ca-channel currents in chick sensory neurons: differential sensitivity to dihydropyridines and $\omega$-conotoxin GVIA. Pfluegers Arch 414:150-156.
Bargas J, Surmeier DJ, Kitai ST (1991) High- and low-voltage activated calcium currents are expressed by neurons cultured from embryonic rat neostriatum. Brain Res 541:70-74.

Bean BP (1984) Nitrendipine binding to cardiac calcium channels: high-affinity binding to the inactivated state. Proc Natl Acad Sci USA 81:6388-6392.

Bean BP (1989) Classes of calcium channels in vertebrate cells. Annu Rev Physiol 50:367-384.

Bertolino M, Llinás RR (1992) The central role of voltage-activated and receptor-operated calcium channels in neuronal cells. Annu Rev Pharmacol Toxicol 32:399-421.

Boland I.M, Dingledine R (1990) Multiple components of both transient and sustained barium currents in a rat dorsal root ganglion cell line. J Physiol (Lond) 420:223-245.

Boll W, Lux HD (1985) Action of organic antagonists on neuronal calcium currents. Neurosci Lett 56:335-339.

Calabresi P, Misgeld U, Dodt HU (1987) Intrinsic membrane properties of neostriatal neurons can account for their low level of spontaneous activity. Neuroscience 20:293-303.

Calabresi P, Mercuri NB, Stefani A, Bernardi G (1990) Synaptic and intrinsic control of membrane excitability of neostriatal neurons. $I$. An in vivo analysis. J Neurophysiol 63:651-662.

Carbone E, Lux HD (1984) A low-voltage activated, fully inactivating Ca-channel in vertebrate sensory neurones. Nature 310:501-502.

Carbone E, Sher E, Clementi F (1990) Ca currents in human neuroblastoma IMR 32 cells: kinetics, permeability and pharmacology. Pfluegers Arch 416:170-179.

Chang HT, Wilson CJ, Kitai ST (1982) A Golgi study of rat neostriatal neurons: light microscopic analysis. J Comp Neurol 208:107-126.

Chernevskaya NI, Obukhov AG, Krishtal OA (1991) NMDA receptor agonists selectively block $\mathrm{N}$-type calcium channels in hippocampal neurons. Nature 349:418-420.

Cherubini E, Lanfumey L (1987) An inward calcium current underlying regenerative calcium potentials in rat striatal neurons in vitro enhanced by Bay K 8644. Neuroscience 21:997-1005.

Coulter DA, Huguenard JR, Prince DA (1989a) Characterization of ethosuximide reduction of low-threshold calcium current in thalamic neurons. Ann Neurol 25:582-593.

Coulter DA, Huguenard JR, Prince DA (1989b) Calcium currents in rat thalamocortical relay neurones: kinetic properties of the transient, low-threshold current. J Physiol (Lond) 414:587-604.

Doerner D, Pitler TA, Alger BE (1988) Protein kinase C activators block specific calcium and potassium current components in isolated hippocampal neurons. J Neurosci 8:4069-4078.

Fedulova SA, Kostyuk PG, Veselovsky NS (1985) Two types of calcium channels in the somatic membrane of newborn rat dorsal root ganglion neurones. J Physiol (Lond) 359:431-446.

Forscher P, Oxford GS (1985) Modulation of calcium channels by norepinephrine in internally dialyzed avian sensory neurons. J Gen Physiol 85:743-763.

Fox AP, Nowycky MC, Tsien RW (1987) Kinetic and pharmacological properties distinguishing three types of calcium currents in chick sensory neurones. J Physiol (Lond) 394:149-172.

Fraser DD, MacVicar BA (1991) Low-threshold transient calcium current in rat hippocampal lacunosum-moleculare interneurons: $\mathrm{ki}$ netics and modulation by neurotransmitters. J Neurosci 11:28122820 .

Galarraga E, Bargas J, Sierra A, Aceves J (1989) The role of calcium in the repetitive firing of neostriatal neurons. Exp Brain Res 75:157168.

Gerfen CR (1992) The neostriatal mosaic: multiple levels of compartmental organization in the basal ganglia. Annu Rev Neurosci 15 : 285-320.

Gottmann K, Rohrer H, Lux HD (1991) Distribution of $\mathrm{Ca}^{2+}$ and $\mathrm{Na}^{+}$conductances during neuronal differentiation of chick DRG precursor cells. J Neurosci 11:3371-3378.

Hamill OP, Marty A, Neher E, Sakmann B, Sigworth FJ (1981) Improved patch-clamp tcchniques for high-resolution current recording from cells and cell-free membrane patches. Pfluegers Arch 391:85100.

Hernández-Cruz A, Pape H-C (1989) Identification of two calcium currents in acutely dissociated neurons from the rat lateral geniculate nucleus. J Neurophysiol 61:1270-1283.

Hess P (1990) Calcium channels in vertebrate cells. Annu Rev Neurosci $13: 337-356$. 
Hillman D, Chen S, Aung TT, Cherksey B, Sugimori M, Llinás RR (1991) Localization of P-type calcium channels in the central nervous system. Proc Natl Acad Sci USA 88:7076-7080.

Hoehn K, Watson TWJ, MacVicar BA (1991) High- and low-threshold calcium currents in acutely isolated striatal neurons. Soc Neurosci Abstr 17:416.3.

Huguenard JR, Prince DA (1991) An unconventional transient Ca current in GABA-ergic neurons of rat thalamic reticular nucleus. Soc Neurosci Abstr 17:142.9.

Hull CD, Bernardi G, Buchwald NA (1970) Intracellular responses of caudate neurons to brain stem stimulation. Brain Res 22:163-179.

Jahnsen H, Llinás R (1984) Ionic basis for the electroresponsiveness and oscillatory properties of guinea-pig thalamic neurones in vitro. $\mathrm{J}$ Physiol (Lond) 349:227-247.

Kasai H, Aosaki T, Fukuda J (1987) Presynaptic Ca-antagonist $\omega$-conotoxin irreversibly blocks N-type Ca-channels in chick sensory neurons. Neurosci Res 4:228-235.

Kay AR, Wong RKS (1986) Isolation of neurons suitable for patch clamping from adult mammalian central nervous system. J Neurosci Methods 16:227-238.

Kita H, Kita T, Kitai ST (1985a) Active membrane properties of rat neostriatal neurons in an in vitro slice preparation. Exp Brain Res 60: 54-62.

Kita H, Kita T, Kitai ST (1985b) Regenerative potentials in rat neostriatal neurons in an in vitro slice preparation. Exp Brain Res 60:6370.

Lemos JR, Nowycky MC (1989) Two types of calcium channels coexist in peptide-releasing vertebrate nerve terminals. Neuron 2:1419-1426.

Leonard JP, Nargeot J, Snutch TP, Davidson N, Lester HA (1987) Ca channels induced in Xenopus oocytes by rat brain mRNA. J Neurosci 7:875-881

Lester RA, Jahr CE (1990) Quisqualate receptor-mediated depression of calcium currents in hippocampal neurons. Neuron 4:741-749.

Lin J-W, Rudy B, Llinás R (1990) Funnel-web spider venom and a toxin fraction block calcium current expressed from rat brain mRNA in Xenopus oocytes. Proc Natl Acad Sci USA 87:4538-4542.

Lledo PM, Homburger V, Bockaert J, Vincent J-D (1992) Differential $G$ protein-mediated coupling of $\mathrm{D}_{2}$ dopamine receptors to $\mathrm{K}^{+}$and $\mathrm{Ca}^{2+}$ currents in rat anterior pituitary cells. Neuron 8:455-463.

Llinás RK (1988) The intrinsic electrophysiological properties of mammalian neurons: insights into central nervous system function. Science 242:1654-1664

Llinás R, Yarom Y (1981a) Electrophysiology of mammalian inferior olivary neurones in vitro. Different types of voltage-dependent ionic conductances. J Physiol (Lond) 315:549-567

Llinás R, Yarom Y (1981b) Properties and distribution of ionic conductances generating electroresponsiveness of mammalian inferior olivary neurones in vitro. J Physiol (Lond) 315:569-584.

Llinás R, Sugimori M, Lin JW, Cherksey B (1989) Blocking and isolation of a calcium channel from neurons in mammals and cephalopods utilizing a toxin fraction (FTX) from funnel-web spider poison. Proc Natl Acad Sci USA 86:1689-1693.

McCleskey EW, Fox AP, Feldman DH, Cruz LJ, Olivera BM, Tsien RW, Yoshikami D (1987) $\omega$-Conotoxin: direct and persistent blockade of specific types of calcium channels in neurons but not muscle. Proc Natl Acad Sci USA 84:4327-4331.

Mensah P, Deadwyler S (1974) The caudate nucleus of the rat: cell types and the demonstration of a commissural system. J Anat 117: 281-293.

Misgeld U, Calabresi P, Dodt HU (1986) Muscarinic modulation of calcium dependent plateau potentials in rat neostriatal neurons. Pfluegers Arch 407:482-487.

Mogul DJ, Fox AP (1991) Evidence for multiple types of $\mathrm{Ca}^{2+}$ channels in acutely isolated hippocampal CA3 neurones of the guinea-pig. $J$ Physiol (Lond) 433:259-281.

Narahashi T, Tsunoo A, Yoshii M (1987) Characterization of two types of calcium channels in mouse neuroblastoma cells. J Physiol (Lond) 383:231-249.
Nowycky MC, Fox AP, Tsien RW (1985) Three types of neuronal calcium channels with different calcium agonist sensitivity. Nature 316:440-443

Penington NJ, Kelly JS, Fox AP (1991) A study of the mechanism of $\mathrm{Ca}^{2+}$ current inhibition produced by serotonin in rat dorsal raphe neurons. J Neurosci 11:3594-3609.

Plummer MR, Hess P (1991) Reversible uncoupling of inactivation in N-type calcium channels. Nature 351:657-659.

Plummer MR, Logothetis DE, Hess P (1989) Elementary properties and pharmacological sensitivities of calcium channels in mammalian peripheral neurons. Neuron 2:1453-1463.

Regan LJ, Sah DWY, Bean BP (1991) $\mathrm{Ca}^{2+}$ channels in rat central and peripheral neurons: high-threshold current resistant to dihydropyridine blockers and $\omega$-conotoxin. Neuron 6:269-280.

Regehr WG, Connor JA, Tank DW (1989) Optical imaging of calcium accumulation in hippocampal pyramidal cells during synaptic activation. Nature 341:533-536.

Sanguinetti MC, Kass RS (1984) Voltage-dependent block of calcium channel current in the calf cardiac Purkinje fiber by dihydropyridine derivatives. Circ Res 55:284-297.

Sayer RJ, Schwindt PC, Crill WE (1990) High- and low-threshold calcium currents in neurons acutely isolated from rat sensorimotor cortex. Neurosci Lett 120:175-178.

Sher E, Clementi F (1991) $\omega$-Conotoxin sensitive voltage-operated calcium channels in vertebrate cells. Neuroscience 42:301-307.

Snutch 'TP, Leonard JP, Gilbert MM, Lester HA, Davidson N (1990) Rat brain expresses a heterogeneous family of calcium channels. Proc Natl Acad Sci USA 87:3391-3395.

Stanley EF (1991) Single calcium channels on a cholinergic presynaptic nerve terminal. Neuron 7:585-591.

Sugimori M, Preston RI, Kitai ST (1978) Response properties and electrical constants of caudate nucleus neurons in the cat. J Neurophysiol 41:1662-1675.

Swandulla D, Carbone E, Lux HD (1991) Do calcium channel classifications account for neuronal calcium channel diversity? Trends Neurosci 14:46-51.

Takahashi K, Ueno S, Akaike N (1991) Kinetic properties of T-type $\mathrm{Ca}^{2+}$ currents in isolated rat hippocampal neurons. $\mathrm{J}$ Neurophysiol 65:148-155.

Tang C, Presser F, Morad M (1988) Amiloride selectively blocks the low threshold (T) calcium channel. Science 240:213-215.

Thompson SM, Wong RKS (1991) Development of calcium current subtypes in isolated rat hippocampal pyramidal cells. J Physiol (Lond) 439:671-689.

Toselli M, Lux HD (1989) Opposing effects of acetylcholine on the two classes of voltage-dependent calcium channels in hippocampal neurons. Experientia [Suppl] 57:97-103.

Tsien RW, Lipscombe D, Madison DV, Bley KR, Fox AP (1988) Multiple types of neuronal calcium channels and their selective modulation. Trends Neurosci 11:431-438.

Wadman WJ, Connor JA (1992) Persisting modification of dendritic calcium influx by excitatory amino acid stimulation in isolated CAl neurons. Neuroscience 45:293-305.

Westenbroek RE, Ahlijanian MK, Catterall WA (1990) Clustering of L-type $\mathrm{Ca}^{2+}$ channels at the base of major dendrites in hippocampal pyramidal neurons. Nature 347:281-284.

Williams PJ, MacVicar BA, Pittman J (1990) Synaptic modulation by dopamine of calcium currents in rat pars intermedia. J Neurosci 10:757-763.

Wilson CJ, Groves PM (1981) Spontaneous firing patterns of identified spiny neurons in the rat neostriatum. Brain Res 220:67-80.

Wilson CJ, Chang HT, Kitai ST (1983) Disfacilitation and long-lasting inhibition of neostriatal neurons in the rat. Exp Brain Res 51:227235 .

Yaari Y, Hamon B, Lux HD (1987) Development of two types of calcium channels in cultured mammalian hippocampal neurons. Science 235:680-682. 